NEW URBANISM IN PRACTICE:

AN ANALYSIS OF THE VILLAGE, NIAGARA-ON-THE-LAKE

By

Kirstin Elizabeth Jensen

MA, McMaster University, 2013; BA, Brock University, 2012

\author{
A Major Research Paper \\ Presented to Ryerson University \\ in partial fulfillment of the requirements for the degree of \\ Master of Planning \\ in \\ Urban Development
}

Toronto, Ontario, Canada, 2016

(C) Kirstin Jensen 2016 


\section{Author's Declaration for Electronic Submission of a MRP}

I hereby declare that I am the sole author of this MRP. This is a true copy of the MRP, including any required final revisions.

I authorize Ryerson University to lend this MRP to other institutions or individuals for the purpose of scholarly research.

I further authorize Ryerson University to reproduce this MRP by photocopying or by other means, in total or in part, at the request of other institutions or individuals for the purpose of scholarly research.

I understand that my MRP may be made electronically available to the public. 


\title{
NEW URBANISM IN PRACTICE: AN ANALYSIS OF THE VILLAGE, NIAGARA-ON-THE-LAKE
}

(C) Kirstin Jensen, 2016

\author{
Master of Planning \\ in \\ Urban Development \\ Ryerson University
}

\begin{abstract}
New urbanism has played an increasingly influential role in Canadian planning and development. Its recent popularity has demonstrated a propensity towards compact, mixed-use, diverse, pedestrian-oriented, and walkable communities, which provide a high standard of architectural design and a focus on the public realm. The Village presents a case study of a growing historic and rural small town which has turned to new urbanism to guide its new development. The traditional design features have proven ideal for a mixed commercialresidential neighbourhood which carefully selected strategies of implementation to protect its local heritage and character in a modern development. This research presents a discussion of the new urbanism, analyzes a typology put forth by Dan Trudeau that helps inform many choice features of The Village as characteristic of Hybrid Urbanism, and explores the extent to which the principles of the movement have been carried out successfully in this case study community.
\end{abstract}

Key words: new urbanism; mixed-use development; Niagara-on-the-Lake; traditional neighbourhood development. 


\section{Acknowledgements}

I would like to thank Professor Keeble for your input, guidance and especially patience in the progress of this research. I also wish to thank Aaron Butler - my second reader - for your willingness to advice and mentor me in this project. Finally, special thanks to John Hawley, developer of The Village, who provided more material on both the movement and the development than I could have ever hoped for. As well, for showing me how much passion and regard can be developed for the concept which has been demonstrated in so many ways in The Village. I hope to bring that same level of interest that has now grown in me for new urbanism into my future career opportunities. 


\section{Dedication}

I would like to dedicate my major research project to my wonderful mother Darka Jensen. You have inspired in me a passion for urban planning that took two prior degrees and a lot of hard work and sleepless nights - for the both of us - before I could come to this realization. Your endless expanse of knowledge and wisdom, and especially your editing skills, that you have willingly provided me over the past seven years of my university career have contributed more than you know to my abilities and my intellect, and are so much a part of the reason I have accomplished as much as I have. Thank you for your persistent patience, love and encouragement whenever I have doubted myself and my goals, and for pushing me to always continue striving for more. I love you!

To my dad Scott, thank you for your constant support and reassurance, and instilling in me from a young age my ambition, determination, spirit and strength to pursue my dreams. You are one of the smartest people I know and I am so thankful that this quality has rubbed off on me even half as much. Also, thank you for always stepping in to be the buffer between Mom and I on those long and stressful nights when we couldn't quite see eye to eye on the subject of the day. I love you too!

To Adam, the completion of this degree could not have happened without you. From the minute I knew I wanted to go back to school, you encouraged and pushed me to go for it, and for that I am forever thankful. I have finally found a field in which I am passionate and excited to work in every day, and you have always supported this process regardless of the energy and money and stress that it cost me, and you. Thank you for your patience, love and understanding, for showing me what true ambition and drive looks like, and for always reminding me of my abilities and your faith in me when I couldn't see them myself. 


\section{Table of Contents}

1. Introduction 1

2. The Congress for the New Urbanism 7

3. New Urbanism in Canada 9

4. The Charter 11

5. A Typology of New Urbanist Developments 17

6. The Municipality of Niagara-on-the-Lake 23

$\begin{array}{ll}\text { 7. The Village } & 25\end{array}$

8. Analysis and Discussion 30

i. The Application of Hybrid Urbanism 30

ii. New Urbanism Practices in The Village 31

9. Conclusion 50

10. Appendix A 53

11. References 


\section{List of Figures}

Figure 1: Settlement Areas of the Town of Niagara-on-the-Lake

Figure 2: The Village, Niagara-on-the-Lake Master-Plan

Figure 3: Phase 3 Master-Plan of The Village

Figure 4: Front porches designed in close proximity to the sidewalk encourage interaction with the public realm

Figure 5: Planned pathways, gathering areas and well lit spaces allow for safe and frequent social engagement among residents

Figure 6: Example of housing type diversity - a single detached home adjacent to a row of townhouses

Figure 7: Excerpt from The Village architectural codes \& urban regulations, looking at schematics for a single detached house plan

Figure 8: Parkettes and public gardens are evident throughout The Village

Figure 9: Example of the provision of open green spaces for residents and visitors alike to enjoy

Figure 10: The presence of a terminating vista, which are planned for almost every road throughout The Village, as well as evidence of narrow streets and sidewalk provision on both sides

Figure 11: Commercial services provided in The Village Centre

\section{List of Appendices}

Appendix A: Charter Criterion Compared to its Satisfaction of Practical Application in The Village 


\section{$\underline{1 . \text { Introduction }}$}

In the early 1980s in a small community on the Florida panhandle known as Seaside, developer Robert Davis and architects Andrés Duany and Elizabeth Plater-Zyberk envisioned a town that could be built effectively for density and walkability in compact, traditional and connected neighbourhoods. This notion eventually coined a concept known as New Urbanism, a concept of which has evolved to encompass an entire means of how to master plan communities. Seaside was designed to bear a resemblance to a small, pre-World War II town, complete with walkable communities, a mix of public and private builds, and shared civic spaces (Banerjea, 2015).

New urbanism offers a movement in urban planning and development centred on the belief that the physical environment plays a specific role in a person's chances for a happy and prosperous life (Congress for the New Urbanism, "The Movement", 2015). A sense of community is thought to be most successfully established from well-designed cities, towns, neighbourhoods and public places - places in which their citizens and businesses can thrive and prosper without fear and worry.

In 1995, Niagara-on-the-Lake, Ontario was immersed in an Ontario Municipal Board arbitration over the best type of development for an area of land that was at the entrance to the historic Old Town. The search for an acceptable option led to the exploration of new urbanism by a working committee of the Town looking for solutions. New Urban architect and town planner Andrés Duany was invited to master plan this new community for the Town. The website for The Village claims that "This genuine community in the making is continually inspired by a love of old Niagara-on-the-Lake, as well as by an appreciation for what other great New Urban communities have achieved." 
This being said, the Charter of the New Urbanism_indicates that a number of significant elements of new urbanism are absent from this development, as well as in other master-planned communities classified as new urbanist recently developed across Ontario. The most unique aspect of The Village that sets it apart from a more traditional new urbanist development is that it is located in a small heritage town, in a rural inspired community, as opposed to the typical urban and metropolitan region builds that typified the original New Urbanist community in Seaside, Florida and those like it across the United States. Despite a number of key differences, The Village has become recognized as a successful embodiment of new urbanism, albeit in a rural setting.

The research questions I intend to investigate are: Can The Village in Niagara-on-the-Lake truly be considered a successful new urbanist community found in Ontario? Are there aspects of this development that make it a more legitimate example of good new urbanism? Does the absence of certain elements of new urbanist design features make a community less new urbanist, or is the definition of what truly is new urbanism in need of expansion for these communities to become more prevalent in Ontario (and perhaps across Canada)?

Dan Trudeau (2013) has suggested that while considerable investigation into the movement of new urbanism has been undertaken over the last decade in particular, the literature has tended towards intensive case studies of particular projects which predominate (Trudeau, 2013). Case study research is indeed crucial to the development of a body of literature on a certain subject or movement, as it offers significant perspectives and insights into the ways new urban principles are implemented and how they can impact the daily lives of citizens of these developments. However this being said, case studies are not sufficient for providing a comprehensive or systematic view of the specific ways characteristics of new urbanism are integrated into their 
community as a whole, and more research has been called for on new urbanism as it is practiced (Trudeau, 2013).

As such, Trudeau (2013) presents the movement with a typology which attempts to address these limitations by providing a comprehensive means for categorizing the types of new urbanism found in practice. This typology will be critically reviewed and utilized as a way to classify the case study being assessed in this research, The Village, because it moves beyond the dualistic categories commonly used of merely infill and greenfield, and rather recognizes that there may in fact be multiple forms of new urbanist projects available for study which use different processes, politics and principles in design and siting that deserve more distinct definition (Trudeau, 2013). 


\section{The Movement}

New Urbanism was established in 1993 by Duany and Plater-Zyberk through the founding of the Congress of the New Urbanism, a non-profit organization interested in promoting the conservation of natural environments, the rebuilding of neighbourhoods and regions into mixed residential, business and retail developments, and the rediscovery of old communities, where community interactions are focused on a courthouse square, public commons, plaza, train station or main street (Banerjea, 2015). The movement itself grew from a desperation brewing in the late 1980s and early 1990s for a new (or renewed) form of development that understood the beauty and logic behind traditional notions of neighbourhood design.

Developers, urban designers, architects, planners, and engineers were increasingly constrained by the prevailing development patterns of the time - which placed impetus on dispersed housing built away from the main squares or focal points of towns - and the urban renewal patterns of which were destroying the fabric of historic neighbourhoods and isolating once-stable communities (Congress for the New Urbanism, "The Movement", n.d.). From this frustration grew an alliance of interested professionals eager to reverse the trend of declining cities. They sought to shape a movement devoted to the reinvestment of development principles focused on design, community and place, dedicated to "reclaiming our homes, blocks, streets, parks, neighbourhoods, districts, towns, cities, regions, and environment" (Congress for the New Urbanism, "The Charter", n.d.).

New urbanists consider the decentralized, auto-dependent suburb as a cause for warning, blaming these forms for the constantly increasing congestion on arterial roads, a lack of meaningful civic life, the loss of open space, limited opportunities for children and others without cars to move about and interact, and for a general discontent among suburbanites 
(Fulton, 1996). The idea was to return to the development patterns that originally made neighbourhoods and cities great before the proliferation of the automobile. For instance, good pedestrian connections, a mix of independent businesses, and access to vast areas of green space through the use of architectural techniques in concert with planning methods to encourage density and walkability at a time when surrounding cities were distracted by big box stores and parking lots (Walker, 2014). With bright paint colours, large shady porches and white picket fences, the idea was "radical but refreshing" and was promptly embraced by cities that sought to reimagine themselves, and particularly their downtowns (Walker, 2014).

The New Urbanism owes much to the City Beautiful ${ }^{1}$ and Garden City ${ }^{2}$ movements of the early twentieth century which led to the latest in a long line of planning and design reform movements that could reinvent the ways in which metropolitan and suburban neighbourhoods are created and renewed. The development of Seaside became the foundation of new urbanism, popularizing the movement towards taming suburban sprawl through the use of 100 -year-old ideas about town planning while using "a very up-to-date knack for appropriating historic building styles" (Jacobs, 2011). Since Seaside, at least 600 new urbanist communities have been developed across the United States, 100 of them in Florida alone (Jacobs, 2011).

A number of different ideas on planning and design principles circulate the new urbanist title, however capturing the core principle of the movement - that community building must occur within a sustainable natural environment. The concept has come to include the following ideals in one manner or another: a regional vision of non-automobile-centric walkable neighbourhoods

\footnotetext{
${ }^{1}$ A reform philosophy of architecture and urban planning in North America that focused on the use of beautification and monumental grandeur incorporated in cities.

${ }^{2}$ A means of urban planning that originated in the United Kingdom and promoted the idea of cities being planned precisely and self-contained while surrounded by green areas, to mix balanced arrangements of residences, business and agriculture.
} 
connected to mass-transit lines, towns with distinct centres and edges, compact neighbourhoods that preserve farmland and environmentally sensitive areas, mixed land-use planning, public gathering places, infill projects in inner-city neighbourhoods, reconstruction of suburban strips, and redevelopment of downtown areas (Banerjea, 2015).

New urbanists are considered partially responsible for creating and popularizing many prevalent development patterns and strategies, including mixed-use development, transit-oriented development, and traditional neighbourhood design, integrating design standards into affordable housing, and designing complete streets (Congress for the New Urbanism, "The Movement", n.d.). New urbanists also claim to be committed to the concepts of strong citizen engagement and participation, ensuring spaces for affordable housing and integrating social and economic diversity albeit these characteristics are less visible and less clearly articulated in neighbourhood design patterns. The new urbanism "strives for a kind of utopian social ideal" (Fulton, 1996), however most proponents find that a communities' physical infrastructure itself can be designed in a particular manner in order to influence certain social arrangements. 


\section{The Congress for the New Urbanism}

In 1993, Duany and Plater-Zyberk, among four other architects - Peter Calthorpe, Elizabeth Moule, Stefanos Polyzoides, and Daniel Solomon - founded the Congress for the New Urbanism (CNU) as a means of advocating for the principles of new urbanism in a non-profit organization that would launch a comprehensive shift in the way communities were built (Poticha, 2013). Shortly thereafter, a set of design standards and values were codified at the fourth Congress in 1996, in the Charter of the New Urbanism (Trudeau and Malloy, 2011).

CNU provided an organizational means to promote the new paradigm for growth which emphasized compact development, mixed land uses, multi-modal transportation and protection of the natural environment (Trudeau and Malloy, 2011). To be specific, in the preamble to the Charter, the Congress is explicit in that they "view disinvestment in central cities, the spread of placeless sprawl, increasing separation by race and income, environmental deterioration, loss of agricultural lands and wilderness, and the erosion of society's built heritage as one interrelated community-building challenge" (Congress for the New Urbanism, “The Charter”, n.d.). As such, the Congress set out to solve these problems head-on.

The Charter is considered to be unique, because it presents both "a vision and a means for accomplishment" (Poticha, 2013). In order to attain the ambitious goals of New Urbanism, goals of which have been meticulously configured and master planned over a number of decades, the CNU sought to educate other design professionals, policy makers and the public through the adjustment of policies and practices that perpetuated destructive development practices, and to do so through their formation of compatible groups that could effect change at all levels (Poticha, 2013). 
To date, hundreds of new urbanist developments and redevelopment ventures have been completed and new zoning codes have been formed which are more effective at promoting mixed-use and walkable urbanism. The CNU has prompted a change in public discourse in regards to cities and development, and has garnered broad recognition that the planning and design of cities and communities can have ramifications in every aspect of public and private life (Poticha, 2013).

CNU's mission is to help build places that are distinct and authentic, and well-designed so that people want to live in them (Congress for the New Urbanism, "The Organization", n.d.). There are currently seventeen local and state chapters in existence and offices in Chicago, IL and Washington, DC, working together to unite the New Urbanist movement. The projects and campaigns undertaken by the CNU work to empower their members' efforts, hoping to foster new ideas and innovative work that can then be dispersed to a global audience, and to identify policy opportunities and articulate new strategies for policy implementation using design approaches (Congress for the New Urbanism, “The Organization”, n.d.). On the same note, CNU projects adhere ardently to the Charter and frequently involve extensive public engagement efforts in order to respond to the genuine needs and interests of their residents, and take into account the visions of how people aspire to live, work, shop and interact. 


\section{New Urbanism in Canada}

Beginning in the 1970s, many Canadian cities strongly promoted principles that are now linked to new urbanism, such as infill development, mixed use, and residential intensification (Grant and Bohdanow, 2008). Grant and Bohdanow (2008) suggest that the St. Lawrence neighbourhood located in Toronto, Ontario for instance, which was redeveloped from an industrial site in the 1970s, can be considered "a kind of precursor to new urbanism" (p.110). In Vancouver around the same time, a similar project called False Creek North which redeveloped a former dump and industrial site with mixed uses and affordable housing also paralleled the new urbanist ideals. Seeking to produce vibrant, dense inner-city communities offering mixed-uses, these early examples provided an idea of what new urbanism would eventually evolve into.

The past two decades have seen an increase in popularity of these principles across Canadian planning theory and practice and have produced substantial research interests as a result. Most municipal plans presently include a number of new urbanist principles such as mixed-use, mixed-income housing, identifiable community centres, distinctive urban design features, and walkable and connected street systems (Grant and Bohdanow, 2008). However, the number of comprehensively planned new urbanist communities in the country is still but a short list, despite the fact that a variety of new urbanism design elements are being incorporated into the market more frequently, but without fully committing to the fundamental principles or label distinctive of New Urbanism (Grant and Bohdanow, 2008).

Whether or not developers are explicitly building projects that adhere entirely to the new urbanist principles is not known, however Grant and Bohdanow (2008) have provided the most comprehensive list to date, of 73 new urbanism communities in Canada as of August 2007. Since the production of this list, researchers have not produced a similar or updated list to the 
same extent. It is thought that Canada largely embraced the movement in the 1990s because sustainable development and urbanism strategies were already being increasingly employed by planners in the countries' major cities, and with the formation of the CNU in the mid-90s, supporters of the movement found a "ready audience in Canada" (p.110) for the principles it promoted (Grant and Bohdanow, 2008).

Planning in Canada is considered to be easier than in the United States (Grant, 2006). With higher densities than can be found in the USA and what some might say is a particularly strong central planning authority, Canada has taken an active approach to government involvement in the shaping of communities (Grant, 2006). The policy and zoning tools in existence and the presence of regional levels of government provide more opportunities for policy and regulation coordination, and as a result when planners or developers have an innovate direction they would like considered, the tools are more readily available to increase the potential of these occurrences.

In the early 1990s, many cities across the country were eager to find strategies to intensify development through urban infill, the redevelopment of industrial lands and using modified policies for suburban areas (Grant, 2006). Government agencies at the time were interested in determining an approach for strategic, sustainable and healthy planning so they funded studies and demonstration projects to assess the advantages of using various approaches. These practices, in combination with visits from key figures of the new urbanist movement from across the United States, resulted in the presentation of a new development standard for Canadian planners which would aid in the integration of the surplus of principles being practiced outside of the formal title of new urbanism (Grant, 2006). This design vision for community planning was 
willingly embraced, and Canadian planners, designers and politicians became increasingly interested in applying the philosophies of new urbanism in a more holistic sense.

In response, many municipalities revised official plans and zoning regulations to include those principles which more accurately depicted the new urbanist way of planning. Changes included modifications to enhance opportunities for mixed use and revised form requirements (Grant, 2006). The Province of Ontario contemplated legislative changes in order to determine a way to contain urban growth within built up areas and increase urban densities, while protecting the valuable agricultural land in area municipalities (Grant and Bohdanow, 2008). In 1997, the Province put forth the Provincial Policy Statement, which advocated for "cost-effective development patterns... for concentrating growth in existing cities, towns, and hamlets", the first piece of evidence towards the integration of new urbanism principles and smart growth (Grant, 2006).

Then in 2006, Ontario adopted Places to Grow, a growth plan for the Greater Golden Horseshoe area around Toronto to limit growth outside of urban areas while setting intensification targets for new development. Planning legislation in Ontario was making an effort to reduce the restrictions on these developments, and to mitigate the effects that regulations and policy would have on the nature of their progress in the future. The popularity of new urbanism among planners and developers was emerging in an obvious fashion and governments were getting on board with the idea of smart growth and urban intensification (Grant and Bohdanow, 2008).

Jill Grant (2006) has argued in a number of books and journal articles that new urbanism has made a considerable impact on planning in Canada over the last decade. Planners have reduced development requirements in a variety of ways, but in particular the allowance of smaller lot sizes and setbacks in both new urbanist projects but as well as in conventional suburbs, and 
minimum lot sizes have decreased in many areas as well (Grant, 2006). She found that many Canadian cities were moving towards a return to pre-automobile standard urban lot widths, and increasing urban densities, implementing mixed use zones and promoting urban revitalization and infill growth. New urbanism developers in Canada have received considerable direction and guidance from architects Duany and Calthorpe on a number of occasions, and many developments have been modelled after a number of American styles of new urbanism, particularly traditional neighbourhood development (TND) and transit oriented development (TOD) (Grant, 2006). 


\section{The Charter}

Many different sets of planning and design principles are strewn throughout the new urbanism field, but most definitions are concrete in their inclusion of the following ideals: "walkable neighbourhoods oriented around the five-minute walk; primary orientation around public transit systems; greater integration of different types of land uses at the neighbourhood level;" (Fulton, 1996) as well as commitment to the concepts of strong citizen participation, affordable housing, and social and economic diversity. Critics have argued that despite the fact that new urbanism contains a variety of attractive ideas, there is some difficulty in believing that any contemporary issues that should arise will be able to be contained in the five broad categories that surround new urbanism, namely scale, transportation, planning and codes, regionalism and marketing (Fulton, 1996).

The original Charter of the New Urbanism was published as a book in 1999, as a "groundbreaking document aimed at reclaiming cities and towns from the destructive force of suburban sprawl" (Congress for the New Urbanism, "The Charter", n.d.). The Second Edition of the book, published in 2013, illustrates how the Congress itself is willing to continue to make necessary changes to better reflect the practices and standards of urban design and development. It is a representation of how the Charter was not meant to be a standing document but rather one with approaches and strategies that would need to evolve and grow in progression with real-world instances of new urbanism in practice. In the Foreword to the Second Edition, Shelley R. Poticha comments that this book provides "an update of the interpretation of the Charter of New Urbanism - but the principles have stood the test of time" (Potachi, 2013). She considers the Charter to have matured into a progression of ideas, ones which were instrumental in ushering in a cultural shift in many peoples thinking about cities. 
In total, there are 27 principles that the Congress for the New Urbanism declared to guide public policy, development practices, urban planning, and design under the Charter. These fall into the following three broad categories: "The Region: Metropolis, City and Town; The Neighbourhood, the District and the Corridor; and, The Block, the Street and the Building" (Congress for the New Urbanism, "The Charter", n.d.). Because this case study review relies heavily on the characteristics at the core of new urbanism, it is appropriate to clarify what these specific elements are:

\section{The region: Metropolis, city and town}

1) Metropolitan regions are finite places with geographic boundaries derived from topography, watersheds, coastlines, farmlands, regional parks, and river basins. The metropolis is made of multiple centres that are cities, towns, and villages, each with its own identifiable centre and edges.

2) The metropolitan region is a fundamental economic unit of the contemporary world. Governmental cooperation, public policy, physical planning and economic strategies must reflect this new reality.

3) The metropolis has a necessary and fragile relationship to its agrarian hinterland and natural landscapes. The relationship is environmental, economic and cultural. Farmland and nature are as important to the metropolis as the garden is to the house.

4) Development patterns should not blur or eradicate the edges of the metropolis. Infill development within existing urban areas conserves environmental resources, economic investment, and social fabric, while reclaiming marginal and abandoned areas. Metropolitan regions should develop strategies to encourage such infill development over peripheral expansion.

5) Where appropriate, new development contiguous to urban boundaries should be organized as neighbourhoods and districts, and be integrated with the existing urban pattern. Non-contiguous development should be organized as towns and villages with their own urban edges, and planned for a jobs/housing balance, not as bedroom suburbs.

6) The development and redevelopment of towns and cities should respect historical patterns, precedents, and boundaries.

7) Cities and towns should bring into proximity a broad spectrum of public and private uses to support a regional economy that benefits people of all incomes. Affordable housing should be distributed throughout the region to match job opportunities and to avoid concentrations of poverty.

8) The physical organization of the region should be supported by a framework of transportation alternatives. Transit, pedestrian, and bicycle systems should 
maximize access and mobility throughout the region while reducing dependence upon the automobile.

9) Revenues and resources can be shared more cooperatively among the municipalities and centres within regions to avoid destructive competition for tax base and to promote rational coordination of transportation, recreation, public services, housing, and community institutions.

\section{The neighbourhood, the district and the corridor}

10) The neighbourhood, the district, and the corridor are the essential elements of development and redevelopment in the metropolis. They form identifiable areas that encourage citizens to take responsibility for their maintenance and evolution.

11) Neighbourhoods should be compact, pedestrian friendly, and mixed-use. Districts generally emphasize a special single use, and should follow the principles of neighbourhood design when possible. Corridors are regional connectors of neighbourhoods and districts; they range from boulevards and rail lines to rivers and parkways.

12) Many activities of daily living should occur within walking distance, allowing independence to those who do not drive, especially the elderly and the young. Interconnected networks of streets should be designed to encourage walking, reduce the number and length of automobile trips, and conserve energy.

13) Within neighbourhoods, a broad range of housing types and price levels can bring people of diverse ages, races, and incomes into daily interaction, strengthening the personal and civic bonds essential to an authentic community.

14) Transit corridors, when properly planned and coordinated, can help organize metropolitan structure and revitalize urban centres. In contrast, highway corridors should not displace investment from existing centres.

15) Appropriate building densities and land uses should be within walking distance of transit stops, permitting public transit to become a viable alternative to the automobile.

16) Concentrations of civic, institutional, and commercial activity should be embedded in neighbourhoods and districts, not isolated in remote, single-use complexes. Schools should be sized and located to enable children to walk or bicycle to them.

17) The economic health and harmonious evolution of neighbourhoods, districts, and corridors can be improved through graphic urban design codes that serve as predictable guides for change.

18) A range of parks, from tot-lots and village greens to ballfields and community gardens, should be distributed within neighbourhoods. Conservation areas and open lands should be used to define and connect different neighbourhoods and districts.

The block, the street and the building 
19) A primary task of all urban architecture and landscape design is the physical definition of streets and public spaces as places of shared use.

20) Individual architectural projects should be seamlessly linked to their surroundings. This issue transcends style.

21) The revitalization of urban places depends on safety and security. The design of streets and buildings should reinforce safe environments, but not at the expense of accessibility and openness.

22) In the contemporary metropolis, development must adequately accommodate automobiles. It should do so in ways that respect the pedestrian and the form of public space.

23) Streets and squares should be safe, comfortable, and interesting to the pedestrian. Properly configured, they encourage walking and enable neighbours to know each other and protect their communities.

24) Architecture and landscape design should grow from local climate, topography, history, and building practice.

25) Civic buildings and public gathering places require important sites to reinforce community identity and the culture of democracy. They deserve distinctive form, because their role is different from that of other buildings and places that constitute the fabric of the city.

26) All buildings should provide their inhabitants with a clear sense of location, weather and time. Natural methods of heating and cooling can be more resourceefficient than mechanical systems.

27) Preservation and renewal of historic buildings, districts, and landscapes affirm the continuity and evolution of urban society.

(Congress for the New Urbanism, “The Charter”, n.d.)

New urbanism contributed to the acceptance of mixed-income communities, integrated civic services, and implementation standards that provided a means for advocating for urbanism at various scales, as well as how to promote the integration of villages, towns and cities in a sustainable and environmentally sensitive way (Calthorpe, 2013). The importance of these guiding principles is what developer Peter Calthorpe refers to as a "new balance point", an urbanism in which conservation and environmental sustainability is prioritized but at the same time allows development which preserves the intensity, cultural richness and liveability of great urban places (Calthorpe, 2013). These comprehensive design principles help prescribe ways to develop the movement's built form. As a result of the variation of scales these elements can be 
implemented in, the impact that they have made on the formation of buildings, blocks, neighbourhoods and municipalities is more than apparent (Trudeau, 2013). 


\section{$\underline{\text { 5. A Typology of New Urbanist Developments }}$}

New urbanism is a difficult movement to classify because of its considerable diversity in the ways in which it can and has been implemented. Over the years that the movement has proliferated, developers have chosen to implement new urban design principles selectively and sometimes incompletely (Trudeau, 2013). Commonly, new urban developments are characterized in terms of "infill" or "greenfield" forms; however these terms are increasingly inadequate at differentiating the distinctions and discrepancies between the different types of new urban communities.

In an attempt to facilitate a new way of thinking about how new urbanism is practiced, Dan Trudeau (2013) has developed a typology of new urban development projects that is founded on the "features of urban design, land use and street configuration which characterize the form and content of the built environment" (p.113). Trudeau wanted to move beyond the infill/greenfield distinction and develop an understanding of the certain design features that constitute new urban projects and create a context to assess these developments.

The importance of this typology to this research can be understood through an analysis of The Village in Niagara-on-the-Lake. This new urban community is evidence of the selection process that uses particular principles throughout the development. As such this typology could possibly inform a way for classifying Ontario developments in particular, as often; the absence of many principles in communities across the province is in reality the result of situations beyond the developers' control. Their absence should not be thought of as taking away from the true new urban classification or from the pureness of the concepts application. 
Important to make note of is that Andrés Duany and Emily Talen (2002) have previously introduced the transect method of planning as a form-based approach to city building. This method is a regulatory code that uses a six-part categorization system for the design of urban environments that corresponds to different intensities of development, ranging from dense urban cores to small-town centres, along the rural-to-urban transect (Duany and Talen, 2002). The authors wanted to distribute urban developments along their transect, so that it would strengthen rather than strain the integrity of each environment (Duany and Talen, 2002). The function of the transect is to provide a way of applying a set of core principles reflecting good urban form to a range of human habitats.

The notion that communities should be walkable, pedestrian oriented, diverse and promote the public space would be intrinsic to every form of environment along the transect regardless of its intensity, so that quality environments can be promoted regardless of whether they are urban or rural (Duany and Talen, 2002). This point is crucial to the argument of this research, as it addresses the criticism that the principles of new urbanism promote a "one size fits all" approach to developing urban form. Rather, the creators of the concept were seeking to be able to apply the new urbanist principles of urban form on a grander, regional scale and not necessarily always in urban, dense, cityscapes. With limited urban land now available for growth as a result of the Provincial Policy Statement, 2014, Places to Grow Act, 2005, and The Greenbelt Act, 2005, it is necessary to acknowledge that the idea that new urbanist principles are intended to be applied on this grander, regional scale makes it much more difficult to implement certain features. As a result, pockets of new urbanism development are going to be inherently 'un-pure' new urbanism.

The transect method is important because together with the Charter, they present a list of normative design principles that are meant for implementation. However, Trudeau suggests that 
in reality, the implementation of new urbanism only somewhat follows theory (Trudeau, 2013). The practical aspects of the design principles are "ultimately affected by the contexts in which developers operate" (Trudeau, 2013). The location of a potential site for development is obviously influenced by the existing built environment in place and how normative design principles can be put into practice; financial and development regulations constrain both planners' and developers' capacity to implement certain design principles as well (Trudeau, 2013).

In fact, a major constraint which can impact infill developments in particular is existing regulations and restrictions which encourage the selectivity of which principles are best to implement, in which case some may be omitted due to circumstances beyond the developers' and designers' control. For instance, the existing surrounding built environment will shape how normative design principles can be put into practice. Kentlands, in Washington, D.C., is a comparable example to The Village and provided a great amount of influence to the Niagara-onthe-Lake development. Their development lacked effective public transit connecting it to other Maryland suburbs in metropolitan Washington (Trudeau, 2013), which is a similar issue The Village faces as well, which will be further investigated.

In a study on new urbanism focused on developments in Canada, Grant (2009) found that differing objectives between institutional stakeholders in a project can lead to more selective practices of implementation as well, when planners and engineers of a municipality have different standards to uphold and have to compromise on the best direction that a project may go. Another study regarding new urban developments has found that efforts to promote affordable housing, revitalize downtown urban centres and the reorganizing of suburban sprawl into neighbourhood districts were either rarely or never applied in the development of most projects 
(Garde, 2004). The commitment of the community's government can also play a major role in which principles may or may not be chosen for implementation as well. This is a crucial aspect of a projects effective implementation.

The typology that Trudeau puts forth suggests that new urbanism is made up of separate and distinct practices. Specifically, it assesses the ways in which street configuration, urban design and land use practices can be intermixed for the development of new urban projects (Trudeau, 2013). As mentioned, typical distinctions of these communities were done so by infill and greenfield classifications. Infill development refers to projects built on land that may or may not have been previously developed but is surrounded by developed land, indicating the practice of filling in vacant or unused lands (Trudeau, 2013). These locations are often located in or near existing clusters of development. Comparatively, greenfield developments are projects built on previously agricultural land or land that was never previously developed, and can be seen as a form of peripheral development that is associated with sprawl (Trudeau, 2013).

At a time when limited new urban developments were available for assessment, the "infillversus-greenfield distinction" was sufficient for describing differences in practice among the known projects; however, these terms continued to be used for the next two decades, when not only did the number of developments grow exceedingly but as well the diversity of practices seen in these places (Trudeau, 2013). Trudeau has provided to the literature on new urbanism a typology that moves past the dualist classification towards a systemic categorization using the different ways urban design and land use practices create built environments under the new urbanist designation. Specifically, it is with the hope of providing a way to account for the diversity in practical characteristics that can be found in these neighbourhoods when the infill/greenfield dichotomy is lacking. 
Undergoing an extremely research intensive survey of 106 new urban projects in the United States, the survey inventoried 62 characteristics of a projects' built environment, covering distinct features intrinsic to new urbanism ranging from street configuration to urban design and land use (Trudeau, 2013). Three types of projects were identified from this process, each one exemplifying an individual approach to implementing the principles of new urbanism. Throughout the study, the typology contributed statistically significant differences in 42 built environment attributes amongst new urban developments (Trudeau, 2013).

Mainstream Urbanism describes medium-density and large-area residential neighbourhoods, in which projects of this cluster exemplify a number of the features prescribed under the Charter for new urban development - social diversity, environmental concern, pedestrian focused, and a mix of uses (Trudeau, 2013). Dense Urbanism typifies projects which have been planned for high residential net density, demonstrating a distinct segment of new urban principles that display a tendency to create vibrant urban places using compact mixed-use design and provides a well-defined district (Trudeau, 2013).

Finally, Hybrid Urbanism can be used to understand a whole host of low-density projects that have selectively chosen to implement certain attributes of the Charter at the expense of others, in concert with additional design features that typify conventional forms of development (Trudeau, 2013). Hybrid Urbanist developments are "emblematic of the selective implementation of NU design principles... urban design and housing diversity in particular - that are well represented in this cluster" (Trudeau, 2013). The significance of these three types of classifications is to provide a comparative and more thorough means of examining new urban neighbourhoods, but as well to recognize similarities that appear across all three types in themes such as geography, housing, land uses, urban design and street configuration. 
One point to note in regards to the provision of housing diversity in new urbanist developments is that although a developer may provide a diversity of housing options, it does not necessarily mean that the developer is trying to incorporate elements of new urbanism. In the case of The Village, the developer made a concerted effort to do so that was apparent and by choice to distinguish and broaden the development. Many developers will provide housing diversity because they are required to by policy, or because they are trying to diversify in the market, not to be new urbanist. The extent to which this is carried out in combination with other new urban ideals will indicate a developer's intention behind this practice.

The argument put forth by Trudeau, which is very much in support of the research being performed in this report, is that there are substantive differences in the built form and accumulation of land uses across each individual new urban community (Trudeau, 2013). As will be further exemplified in an analysis of The Village, Hybrid Urbanism provides an ideal typification of the characteristics of its development, as it recognizes the effort put into the details and the attention to the principles of new urbanism present in its development while also supporting the fact that in some circumstances, certain principles are not able to be implemented in all new urbanist projects, but this fact should not be used to detract from the purity of the new urbanist intentions throughout the development. 


\section{The Municipality of the Town of Niagara-on-the-Lake}

Niagara-on-the-Lake is one of 12 area municipalities that make up the greater Regional Municipality of Niagara in the Province of Ontario. The Niagara Region is comprised of Fort Erie, Grimsby, Lincoln, Niagara Falls, Niagara-on-the-Lake, Pelham, Port Colborne, St. Catharines, Thorold, Wainfleet, Welland and West Lincoln. Niagara-on-the-Lake is located on the Canada-United States border. Directly across the river from the Old Town of Niagara-on-theLake and along the Niagara Parkway are Youngstown and Lewiston, and residents of the Niagara Region have access to four bridges in order to enter the United States. The Municipality of the Town of Niagara-on-the-Lake is predominantly rural, and comprised of five distinct settlement areas with urban residents - Virgil, St. David's, Queenston, the Old Town, and Glendale. The Village is located in the Old Town neighbourhood of the Town.

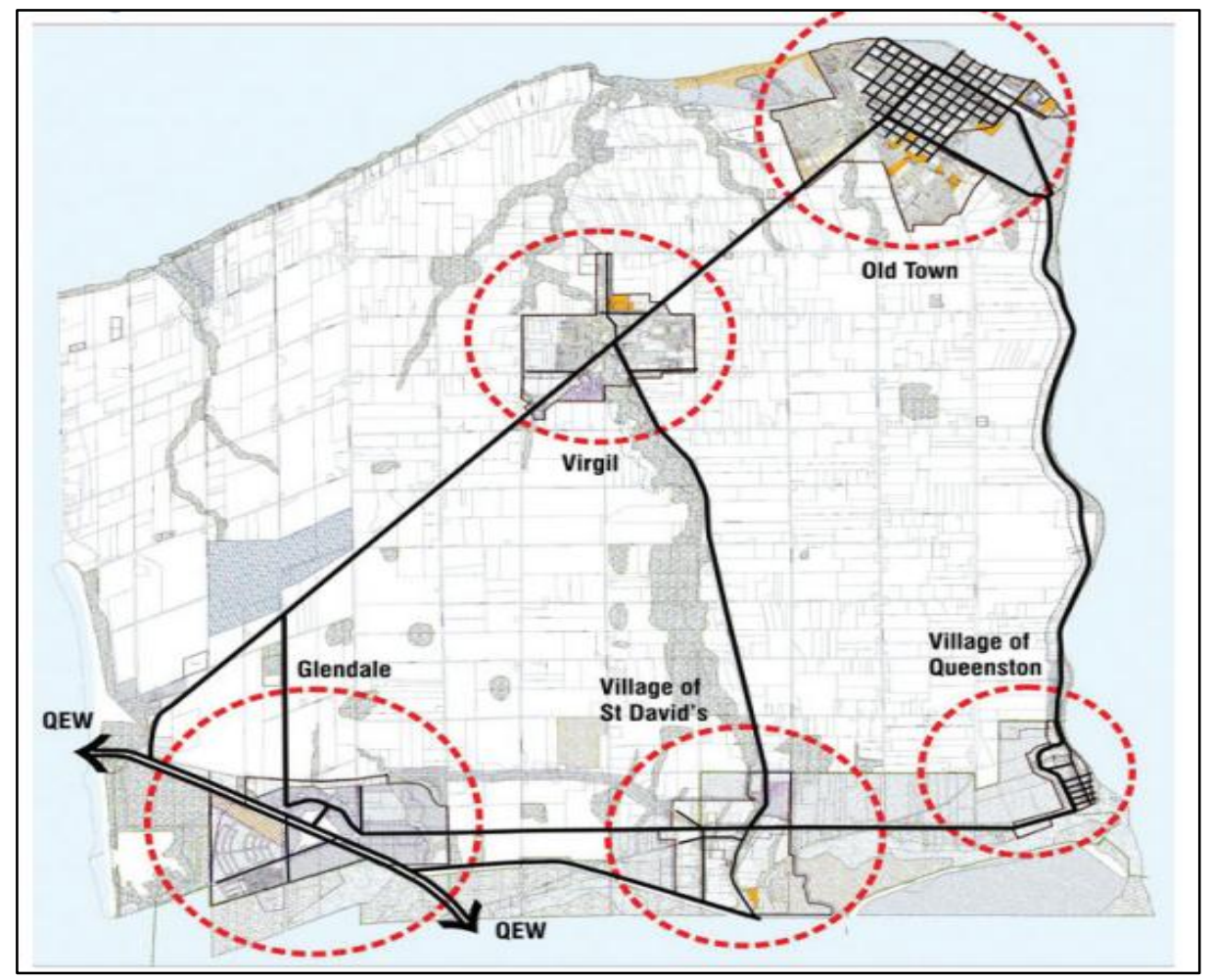

Figure 1 Settlement Areas of the Town of Niagara-on-the-Lake Source: Niagara-on-the-Lake, Niagara-on-the-Lake Current Situation Report and SWOT Analysis, 2012 
The current population of the Town of Niagara-on-the-Lake is approximately 16,000, a population level of which has remained relatively stable over the past several decades (Niagaraon-the-Lake, 2012). The Region of Niagara is predicting that by 2031, Niagara-on-the-Lake will grow by $47.4 \%$ to a total population of 22,700 (Niagara-on-the-Lake, 2012). A Current Situation Report produced in 2012 by the Town indicated that with a median age for the town of 49.1 years, Niagara-on-the-Lake is well above the provincial median age of 39. It has been necessary for Niagara-on-the-Lake to consider the impacts of an aging population in order to position itself to effectively address the challenges in the future. As of 2012, 24.1\% of residents were over the age of 65 , and at the same time, the number of youth in the Town continues to decrease, with only $14 \%$ of the population being under 14 years old (Niagara-on-the-Lake, 2012). This has proved to have a significant impact on the demographics of the resident population that has purchased homes in The Village development, with a noticeable trend towards middle-aged to retirement-age residents comprising the most prevalent age bracket.

The development lands of The Village are located to the north of Niagara Stone Road (also referred to as Highway 55), which is a main transportation route into the Old Town and provides direct access into the commercial and historical area of Niagara-on-the-Lake; to the south and west of Mary Street, and to the east of Niven Road within the urban boundary of the Old Town. There are distinct urban boundaries to the west and south of The Village development. The Village is adjacent to a conventional suburban development to the north known as Garrison Village. To the east of the development is Two Mile Creek Conservation Area watercourse, which provides a natural ravine to residents and visitors alike to the Town. 


\section{The Village}

The Village in Niagara-on-the-Lake was founded in 1998, as a result of a contestation which began in 1995 over the best type of development suitable to welcome visitors and residents alike into the Old Town of the community. As a town recognized for its rich history and distinctive character and architecture, the thought of a strip mall or suburban sprawl framing one's venture into the area were strong controversial options. The Ontario Municipal Board chairman at the time declared a one year moratorium over the discussion in an unpredictable act, and suggested a stakeholder working committee be struck to attempt to determine an alternative (The Village Niagara, “A Historic Beginning”, n.d.).

In the following years, this search led to the exploration of New Urbanism as a movement that had the capacities to find a home in the Old Town of Niagara-on-the-Lake. Developer John Hawley and his wife, Liz, well known for "outside the box developments" were asked to partner in the lead of this working committee (The Village Niagara, "A Historic Beginning", n.d.). As a result of a visit to Seaside in Florida, Hawley was convinced that new urbanism was the form of development that would best compliment the heritage community of Niagara-on-the-Lake, and could contribute rather than detract from the built environment of the town.

In partnership with world renowned planner and architect Andrés Duany, The Village was master-planned and contrived through an engagement process unlike any other this community had ever seen. Taking influence from another of Duany's developments - Kentlands in Washington, DC - the Lord Mayor at the time was also avidly committed to this form of development and believed it to be a correct fit for a town of Niagara-on-the-Lake's unparalleled nature. Undergoing a weeklong Charrette, Duany and his carefully picked team studied the intricate ins and outs of the Old Town, assessing street widths, building heights, and density 
requirements in order to develop an inventory of the architecture unique and distinct to the Town (The Village Niagara, “A Historic Beginning”, n.d.).

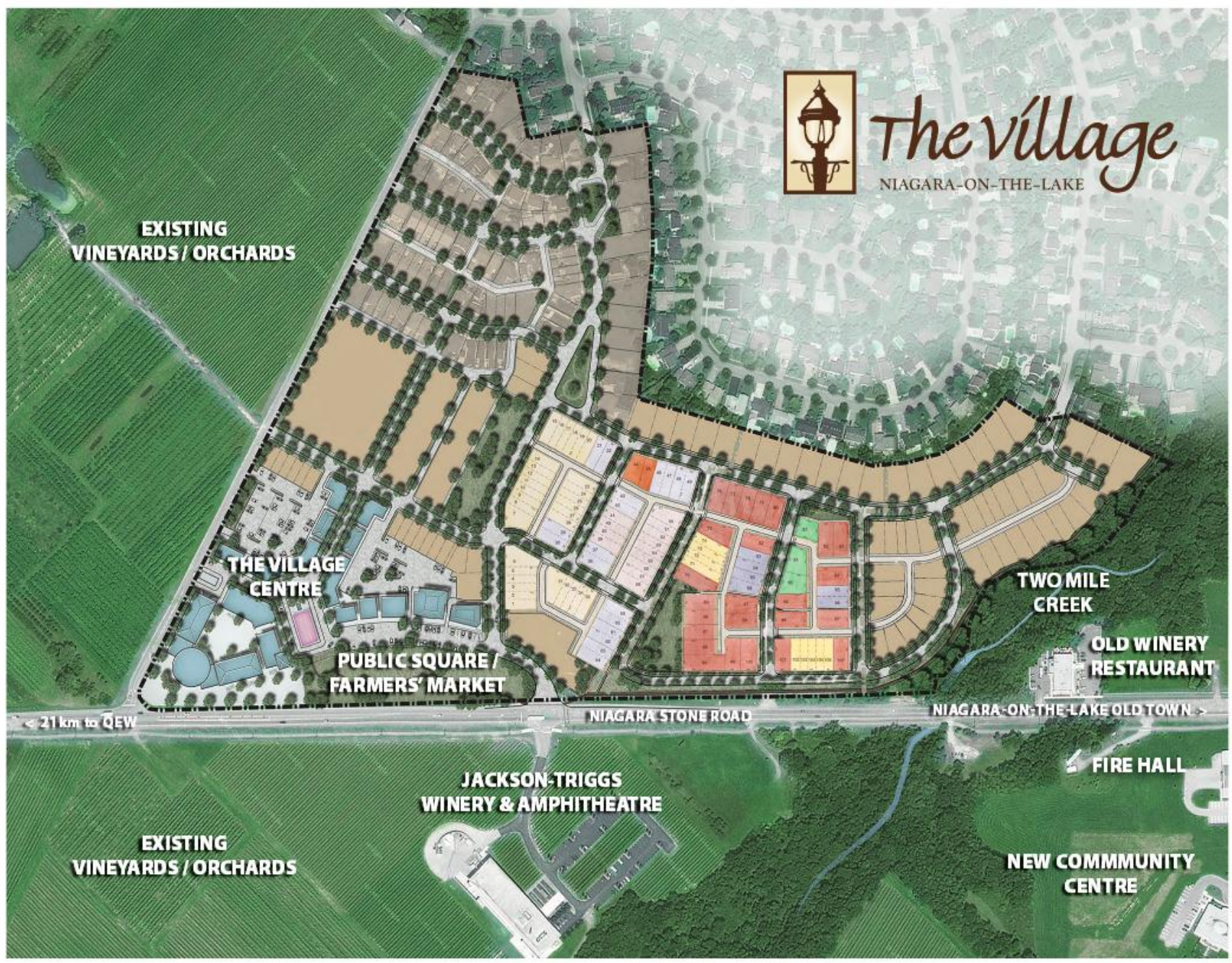

Figure 2 The Village, Niagara-on-the-Lake Master-Plan Source: John Hawley, Developer of The Village, Personal Correspondence, 2016

As a result of this undertaking, "an incredible Master Plan and Architectural Code" was created for The Village (The Village Niagara, "Understanding New Urbanism", n.d.). Made up of walkable streets, intricately detailed buildings, and a variety of public spaces and connections to the public realm and with a Village Centre at its heart, the Master Plan was unanimously 
approved not only by Council but by most of the Niagara-on-the-Lake community. Never before had such consensus and unanimity been achieved for the Town, while at the same time incorporating public engagement and consultation throughout the primary stages of its planning to ensure that the residents of the community were involved throughout and pleased with the final outcome as well. The design of this new community was focused on optimizing the quality of life for its residents and its visitors, while complimenting the unique heritage and culture which can be found in Niagara-on-the-Lake (The Village Niagara, 2016).

The Village is very distinct from a typical suburb, as not only was it designed to resemble traditional neighbourhood towns but it was done so while keeping in mind the architectural heritage of Niagara-on-the-Lake to ensure it was truly characteristic of the Old Town traditions. Also classified as a Traditional Neighbourhood Development (TND), it differs from its suburban counterpart or a Conventional Suburban Development (CSD) in a number of significant ways. CSD's tend to draw attention to the distinct designs of individual houses, and perfecting an ideal private realm for their residents at the expense of the importance of the public realm and its relation to the surrounding community. CSD's also typically create inherent segregation by age and income, by type of residence, and by use (The Village, "Understanding New Urbanism", n.d.).

In comparison, The Village as representative of a TND or New Urban build, has drawn on those specific characteristics that can be found in a CSD and meticulously sought to provide the opposite:

"Duany considered such details as the width of the streets, as well as where significant buildings would be placed. Architectural standards were established to ensure that buildings related to one another and were of the highest standard. Streets were scrutinized to ensure each had a unique and pleasing streetscape. Buildings were placed at strategic vista 
terminations to delight the eyes of the pedestrian or driver. Even the streetlights were carefully chosen and located. And wherever possible rear lanes for garages were utilized so that front doors and not garage doors would highlight the frontages of the residences."

(The Village, “Understanding New Urbanism”, n.d.)

The Village was developed in a designated greenfield area, which is defined by the Places to Grow Act, Growth Plan for the Greater Golden Horseshoe as "the area within a settlement area that is not built-up area; where a settlement area does not have a built boundary, the entire settlement area is considered designated greenfield area" (Places to Grow, 2006). Niagara-onthe-Lake contains a number of undeveloped areas of greenfield lands that are surrounded by built-up urban areas. The first phases of development in The Village produced 186 units of available housing. Current development in The Village has been undertaken by Brookfield Residential Ontario, and the most recent phase of the development producing 41 units in total is scheduled for completion in 2016. Available units range in price from $\$ 529,990$ to $\$ 799,990$ which is representative of the majority of the housing values for the development (Brookfield Residential, 2016). 


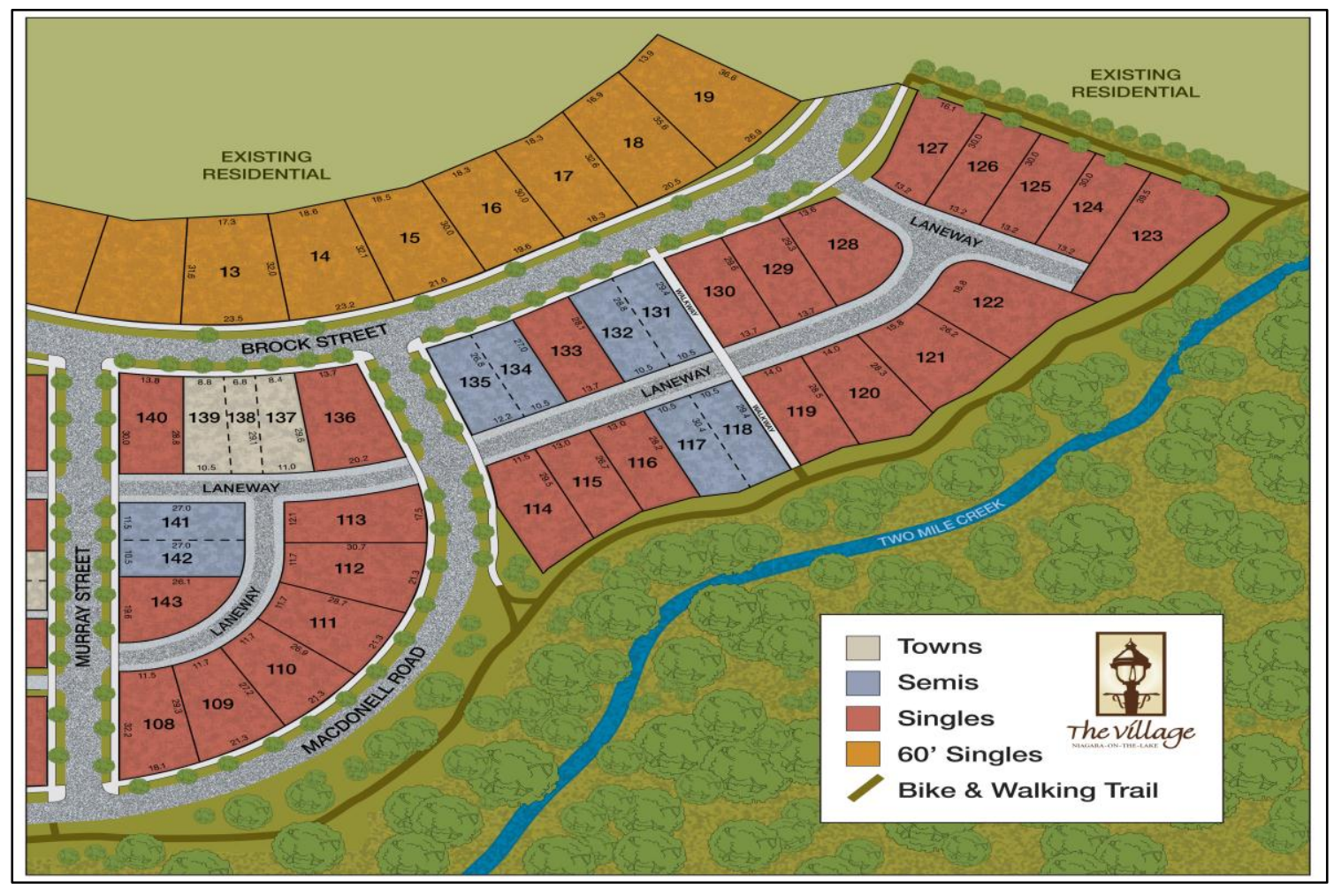

Figure 3 Phase 3 Master-Plan of The Village Source: Brookfield Residential, Community Plan, 2016

The succeeding sections of this report will provide a more in depth analysis of the details of The Village, and its' New Urban characteristics, to provide a better understanding of how new urbanism was methodically incorporated into the entirety of its development, and to explain why - despite distinct principles being absent from its Master Plan - it is still considerably a new urbanist community. 


\section{Analysis and Discussion}

\section{The Application of Hybrid Urbanism}

The following discussion will be divided into two sections. Firstly, an analysis of the principles of new urbanism in their practical implementation as evidenced by Trudeau's typology. The purposes of this will be to demonstrate how there are substantive differences in the built form and mix of land uses that can be found in new urban developments, and to concretely establish why The Village falls into a category of Hybrid (New) Urbanism. Secondly, an analysis of The Village itself will follow, focusing on the distinct and unique aspects that were selected for implementation and how they contribute to the comprehensiveness of The Village as an established new urban neighbourhood, while as well providing a discussion of those elements which were absent or not included, and why.

When looking at geographic characteristics, Hybrid Urbanism developments tend towards large residential neighbourhood projects which will feature retail strips, mixed-use marketplaces, and/or town centres (Trudeau, 2013). Projects in the Hybrid category are also found to be disproportionately located on peripheral greenfield locations, features of which are all true of The Village. These projects are also associated typically with smaller cities, and will also tend to have significantly lower average numbers of housing units.

In terms of street configurations, new urban principles stress the need for built environments which are pedestrian-oriented and conducive to walking, and other non-automobile modes of travel (Trudeau, 2013). The author points out that all three categories were committed to some degree of new urbanist strategies for pedestrian-oriented street configurations, including in almost all situations evidence of sidewalks, marked pedestrian crossings, and a grid pattern 
formation (Trudeau, 2013). Hybrid Urbanist developments displayed a higher use of cul-de-sac and loop features, and a more unorthodox street design system throughout projects.

Urban design features were consistent amongst the categories as well. New urbanism's emphasis on ensuring a focus is placed on shaping built environments to be integrated with public realms will encourage social interactions. For non-residential buildings, they are designed to connect with the street in pedestrian friendly manners and allow for chance interaction in the public realms. More specifically, the Hybrid Urbanism projects tend to demonstrate two critical urban design practices - that is, placing the front façade adjacent to sidewalks and placing residential units above street level shops (Trudeau, 2013). While it is arguable that this is a commonality among most new urban projects, the author found that these features were far more prominent in Hybrid projects in comparison to the other two categories.

Another important design feature that is characteristic of this category is the planning of residential buildings in such a way as to ensure the building and street meet in a favourable manner for pedestrianism, as well as the support of casual interaction amongst residents. The developer of The Village has made it more than apparent that these considerations were also made in the design features of their project. To accomplish this, the use of uniform setbacks, porches and rear-loaded garages are frequently found in Hybrid clusters (Trudeau, 2013).

A mix of land uses are a trademark of new urbanism. Because Hybrid Urbanism projects are more commonly large-area and low-to-medium density developments, it is commonplace to find a large diversity of housing options available for residents. This is a main tenet of new urban principles. Affordable housing options were present evenly across all three development clusters as well, however this feature is often one of the characteristics that is left out or not prescribed to as strictly as others in practice. 
There are significant differences evident in the composition of non-residential land uses found amongst the three clusters of projects. Mainstream Urbanism projects for example have a significantly higher average of non-residential uses, and these will tend to include civic buildings, light industry, and private clubs. In comparison, Hybrid Urban projects include significantly lower than average numbers of adjacent land uses, and the least diverse mix of land uses as well. While commercial and retail land uses are found in a majority of Hybrid Urbanism projects, entertainment, lodging and transit land uses are all present to a much lesser extent (Trudeau, 2013).

This is another particularly indicative reason as to why The Village should rightly be classified as Hybrid. Described as a consequence of the tendency for Hybrid projects to be developed in greenfield locations, it adds to the explanation for why these projects are adjacent to a lower average of differing land uses as well, and to a significantly lesser extent tend not to be located near to civic, entertainment, government services, lodging, medical, office or transit land uses. This is not to say that these projects do not mix an array of land uses whatsoever though. 


\section{New Urbanism Practices in The Village}

Part two of this analysis will take an in-depth look at The Village itself and review its particular characteristics of which the developer has meticulously chosen as central to a well-planned new urban community. Based on personal correspondence with the innovator of the community, the passion and knowledge for new urbanism that was built into this development in an array of ways is more than apparent as one begins to assess the intricate details of The Village. From visits to Seaside and Kentlands, what he saw and learned sparked in Hawley a true love for the movement, and from that point forward he desired to build a new urbanist development in Niagara-on-the-Lake in its purest possible form.

However, many aspects of the location of this development imposed certain hindrances on the development that detracted from its fulfillment of an entirely new urbanist build. This section will investigate a number of fundamental principles that are directly reflected in, or absent from, The Village development; a complete listing of Charter criteria and The Villages' capacity to satisfy these conditions can be found in Appendix A. What is important to remember about the concept of new urbanism is that it is through and through practise based, not a purely theoretical or academic enterprise (Ellis, 2002). Ellis (2002) has provided literature on the new urbanism movement in terms of critiques and rebuttals. A number of these critiques are directly applicable to The Village and therefore Ellis' research will be used as context for evaluating many of the specificities found throughout, while also incorporating in the principles of the Charter of the New Urbanism for comparative sake.

The first and foremost point that Hawley stressed about The Village is how important the public realm is to the entirety of the development. In every sense of the planning, attention to the public realm was kept in mind, ensuring that all setbacks, placement of front doors and porches, street 
patterns, and proximity to neighbours and sidewalks were designed with considerable attention given to how these features will impact and encourage the public space of the community, and inspire the residents to interact with one another in every sense of the word. Hawley was cognisant of the fact that an adjacent existing subdivision was centred on an individual's private space, designed paying little attention to a home's proximity to the sidewalk or ways in which small details can help build a sense of place and community for its residents. He sought to rectify this by focusing rigorously on the interaction with the public realm in every detail of The Village.

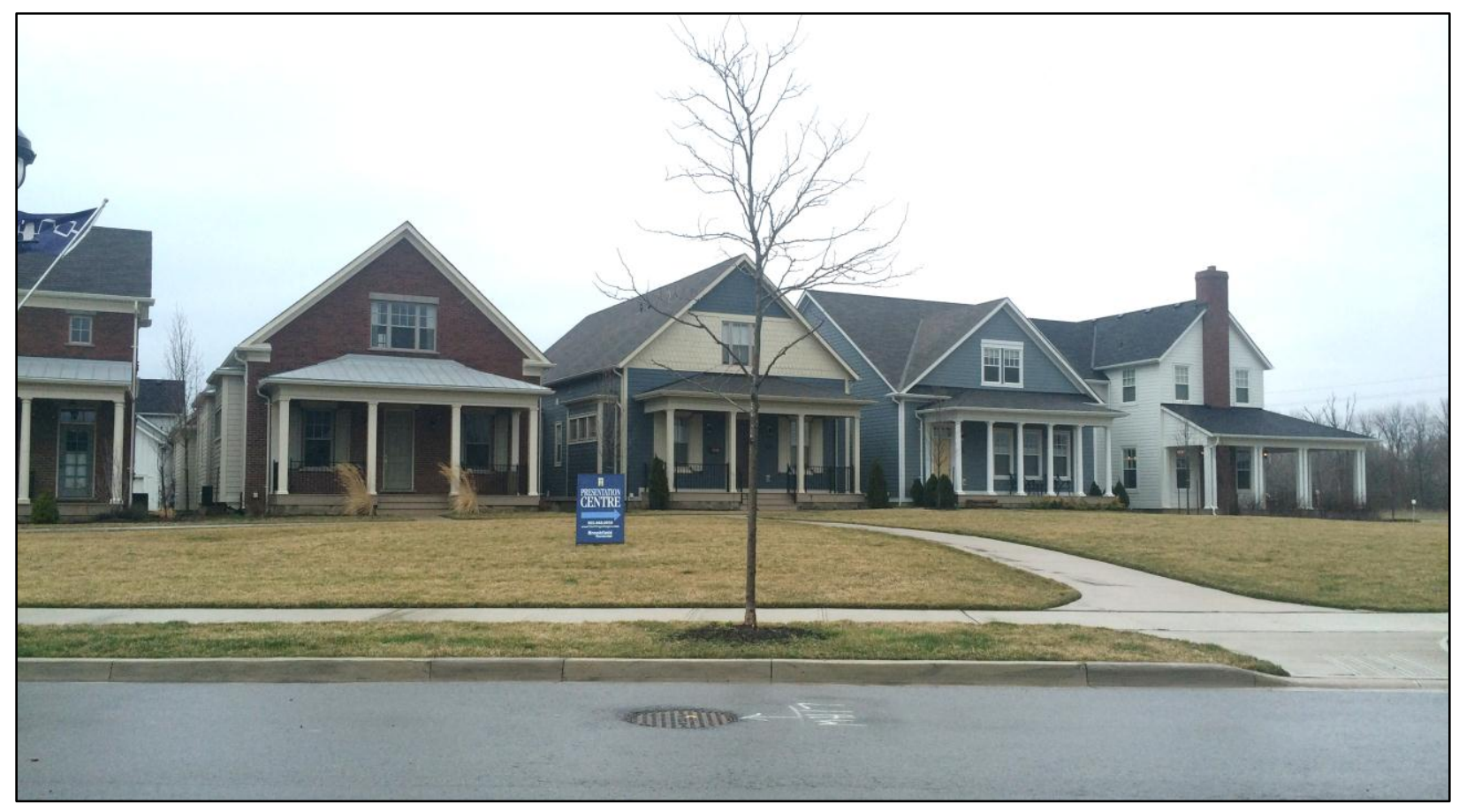

Figure 4 Front porches designed in close proximity to the sidewalk encourage interaction with the public realm

New urbanism is meant to provide for localized, place-based and as well "non-place" social networks (Ellis, 2002), using well-designed streets and public spaces which allow for supportive environments for socializing and community. It is critical that new urban plans do not include 
gates or walls, but rather encourage visitors and community interaction to take place. One critique of the movement is that it attempts to "create" a sense of community with particular spatial arrangements; however the theory merely suggests that the built environment is only one portion of the entirety of the concept and that there is potential for a connection to be made between urban design and sense of community, albeit not the only connection (Ellis, 2002).

The concept does not suggest that this aspect is sufficient on its own to generate that community sense, but it successfully facilitates social interaction in public and semi-public spaces in combination with other variables which a community depends upon. The Village harnesses that one critical aspect of community and uses an extensive network of public pathways, spaces and activity nodes to enhance the neighbourhood feeling and utilizes good design to support and encourage social interaction.

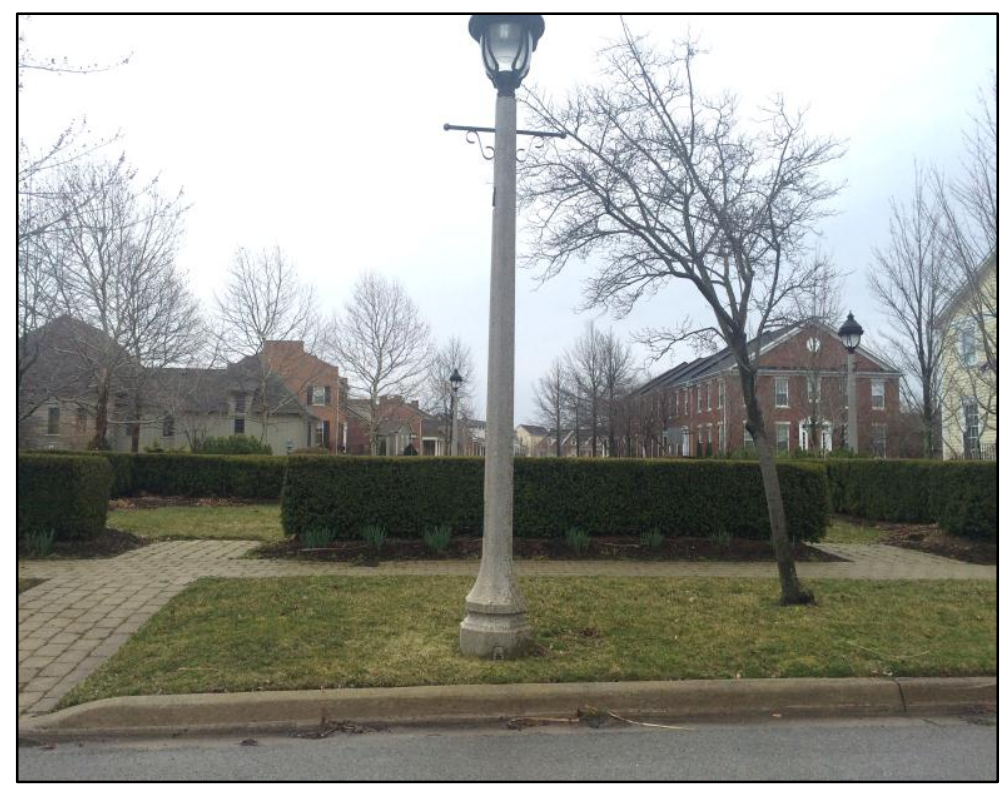


Another tenet of new urbanism suggests that within neighbourhoods, a broad range of housing types should be available, at varying price levels to bring people of diverse ages, race, and incomes into daily interaction. Andrés Duany has pointed out a number of times that great efforts have been made in many projects to introduce as much variety, complexity and originality as possible within the limitations of current land development restrictions (Ellis, 2002). He has explained that there is far more variety in the towns designed for new urbanism than in conventional suburbia, as sites are divided into lots and single builders are not permitted to build whole sectors so as to ensure that all houses are not cookie cutter replicas of one another. Critics have argued that new urbanist communities have a certain inauthenticity to their developments. However, the counterargument is that these developments are still quite new in many areas and because of their blend of mixed uses and different housing types they stand a better chance of evolving in interesting ways into the future that are not yet known.

The Village itself is a prime example of this. When planning for the housing types of the development, a variety of housing options was a key feature that Hawley hoped to instill throughout the project, and the success of this is more than apparent. The planning of this community allowed for single detached homes to be dispersed throughout the lots and could be situated directly beside townhouses, which are placed beside more single detached homes on its opposite adjoining lots, or beside semi-detached homes. There is no segregation of housing types in The Village; integration of styles is central to the design as it hoped to provide another way in which to encourage residents of all ages and income levels to feel able to live in the community without fear of division or seclusion. 


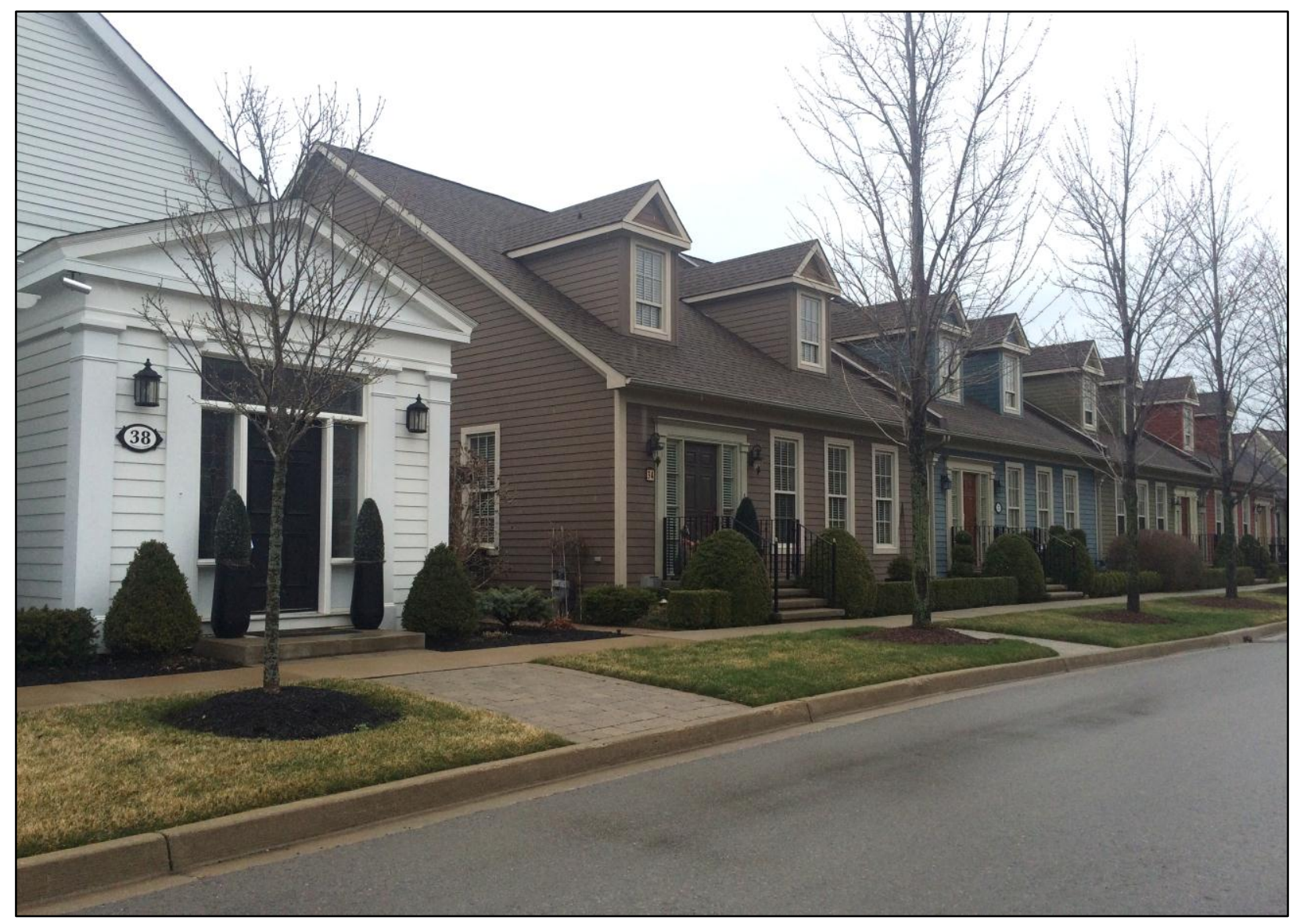

Figure 6 Example of housing type diversity - a single detached home adjacent to a row of townhouses

The range of housing types in The Village includes single detached homes, townhouses, semidetached homes, live-work apartments, and an apartment building structure to be built in time as well. Hawley also explains that there are a certain number of times a certain feature or style of architecture is "allowed" to be built within The Village, and once that style has reached its limit it is no longer on the market as an option for new homebuyers or builders regardless of how much one is willing to spend or argue to have that design. This further supports this new urban characteristic, not only through the provision of different housing types but also by the inclusion of a regulated amount of architectural features and styles that can be found throughout.

A number of critics have argued that the new urbanism is intrinsically oriented to the upper middle class, perpetuates segregation by class, age and income levels, and can be accused of denying cultural difference (Ellis, 2002). On this point, The Village has made both in-roads and 
shortfalls. However, an important point to make is that the context of where The Village is built plays a major role in why this principle may not be able to be achieved to its fullest. Where possible, the developer made efforts to mix housing types so that residents of different forms of housing would not feel that because one lived in a single detached home, they were of a higher income bracket than someone residing in a townhouse. However, regardless of some efforts, the Old Town urban area of Niagara-on-the-Lake has much higher than average market value assessment of properties throughout the Town and the broader Regional Municipality of Niagara, and this imposes a limit on what income brackets truly can afford to reside in the community.

Therefore, despite best intentions for The Village and many other newer new urban developments in Ontario in particular, the market prevents many people below the upper middle class from investing in these homes and as such this principle of new urbanism has not successfully been achieved in The Village. Another shortcoming of this case is that because of the housing prices, and the tendency for Old Town Niagara-on-the-Lake to be a retirement destination, it results in a lower average of young professionals and families being capable of residing in the area.

Rather, it tends to favour middle-aged to retirement-aged residents. However this is not to suggest that The Village intentionally made any choices to restrict access to certain classes or age groups, as the mix of housing forms and availability of live work residences demonstrate a willingness to be inclusive and more accessible to all age and income brackets. There is reason to hope that because a variety of housing types are present, the neighbourhood may stand a chance over time of attracting young professionals and new families to moving in as opposed to remaining completely exclusive. 
Another critique suggests that new urbanism developments are guilty of not allowing residents to participate in the creation of their communities, and are designed to have no potential to accommodate future residents. However, the CNU Charter explicitly endorses a participatory approach to urban design and planning, and often involves spirited discussions about methods for improved public involvement. Charrettes are commonly used to solicit community input and to educate residents about design alternatives (Ellis, 2002). With the goal being to achieve an appropriate balance between professional expertise and community input, charrettes which are followed with additional means of citizen participation can produce fair and consensual outcomes of high quality.

The new urbanism has actually advocated far more openness to public participation than would be found in a CSD, and many steps were made to ensure this was the case in The Village which effectively demonstrates this fact as well. The Village development process included significant community engagement; considering the origin of the idea was as a result of an OMB case to dilute community contention around the best entrance to the Old Town, Hawley was interested in ensuring that this development would have both Council and community support throughout the process. As well, that its design and architectural features would be respectful of the recognized heritage and character of the Town and done so in a way that was satisfactory and pleasing to current residents. In particular, by undergoing a week long public planning exercise that was headed by Duany, the Charrette experienced a turnout of hundreds of town residents interested in having a say and being a part of the process, and when possible any feedback was incorporated to the best of their abilities into the overall development.

A number of principles of new urbanism touch on architectural features as intrinsic to promoting good urban design throughout their developments. In particular, individual architectural projects 
should be seamlessly linked to their surroundings so as to transcend style; as well as the design of streets and buildings should reinforce safe environments, but not at the expense of accessibility and openness; all urban architecture and landscape design is the physical definition of streets and public spaces as places of shared use; and architecture and landscape design should grow from local climate, topography, history, and building practice (Congress of the New Urbanism, "The Charter", n.d.).

The Village has produced an architecturally codified development, in which specific design elements have been protected by code as being intrinsic and unique to any building created in the community. The regulations were designed to produce buildings which are compatible with the historic architecture of Niagara-on-the-Lake, incorporating Georgian to Italian Renaissance ideals to capture this authentic architecture (Duany Plater-Zyberk \& Company, 2007). For example, in order to keep with the traditional styles of architecture found throughout the Town, garages are placed out of sight on rear-laneways, authentic materials such as clapboard, brick, board and batten and stone are employed, and houses and porches are planned for situation close to the street (The Village Niagara, "Niagara-on-the-Lake”, n.d.). The Village Codes are designed to facilitate the "architectural harmony of The Village in Niagara-on-the-Lake" and all property owners are bound by these and the requirements contained in the very detailed document. The Codes discuss such features as materials and configurations and techniques, and miscellaneous elements such as exterior colours, for walls, elements including chimneys, columns, porches and stoops, roofs, signs, windows, doors, and shutters (Duany Plater-Zyberk \& Company, 2007). 


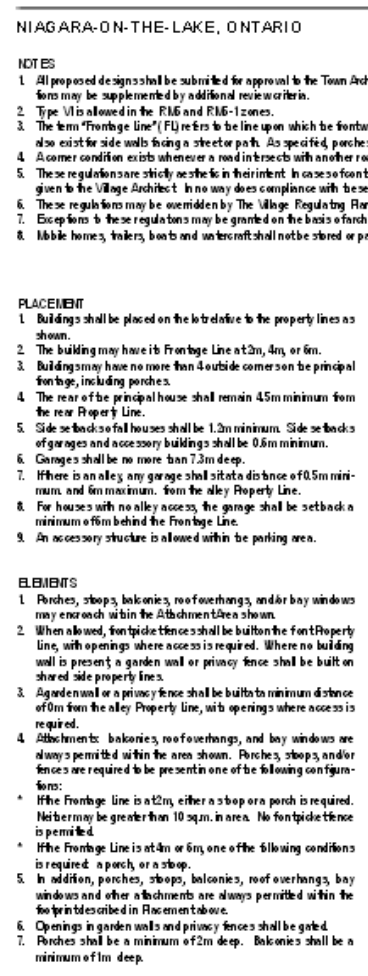

DT ES

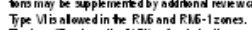

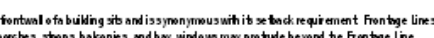

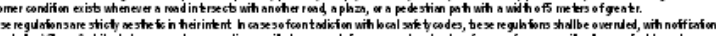

He

on site exeptifinide a garme.

USE
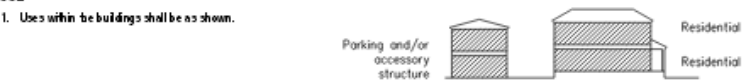

IER
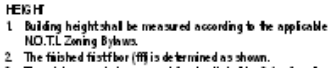

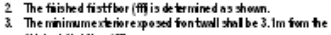

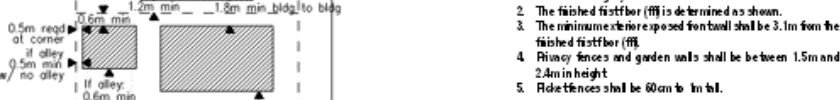

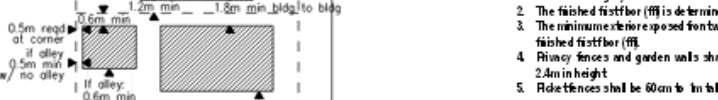

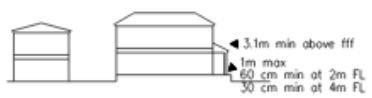

Lot width: $8.5 \mathrm{~m} \mathrm{~min}$
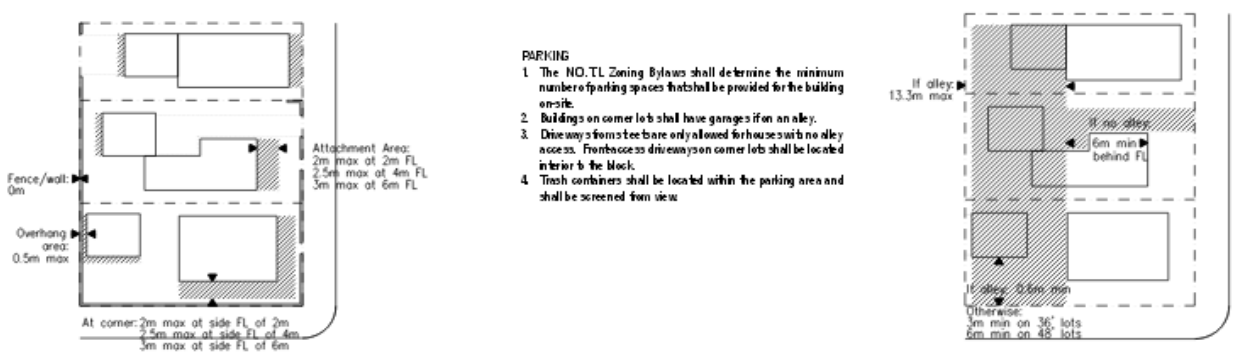

O:M DUANYPLA TER-ZRERK \& COMRPNY

Figure 7 Excerpt from The Village architectural codes \& urban regulations, looking at schematics for a single detached house plan

(Source: John Hawley, Developer of The Village, Personal Correspondence, 2016)

There are two significant points to make on the subject of the Codes. Firstly, these features which are very important and unique to The Village can be quite difficult to implement through traditional zoning by-law regulations, which are used throughout most municipalities in Ontario and Canada. As a result of a good relationship and mutual understanding between the developer and municipal administration, The Village has produced an agreement that allows for these to be successfully implemented without need for additional variances. Secondly, developer John Hawley administers these Codes personally which is a critical responsibility to bear - one that many developers would not take on. This presents a potential argument for why new urbanism is not used that often or at least to its' purest capacity with exceptional architecture and attention to detail. 
Critics of the architectural codes of new urbanism have suggested that they are a "kind of aesthetic quicksand, pulling architects back into the past, denying both historical change and individual inspiration" (Ellis, 2002, p.273). However, Ellis (2002) suggests that these critiques are based upon an unrepresentative sample of new urban projects and ignores how these communities actually function. In reality, there is reason to believe that movements that respect local context are actually more consistent with socially progressive urban policies. Duany has continuously stipulated that new urbanist developments can be built anywhere and in a variety of styles, so long as the real character of streets and place is kept up (Ellis, 2002). It is safe to say that this was a key requirement that can be found throughout the entirety of the design of The Village.

New urbanism attempts to provide a balance between individual choice and public responsibilities, and there is no reason to believe that all forms of architectural codifications are repressive or that some codes are better than others, as has been suggested (Ellis, 2002). The Village has designed a set of individual and unique codes which resulted in a high-quality project that respects the importance of traditional heritage to the community within which it was built while also acknowledging that certain aspects of urban design will provide better, more welcoming and public communities that can foster social interaction and a sense of place for their residents. The vision for The Village has been inspired by a love of the old historic Niagaraon-the-Lake while incorporating elements of what other great new urban communities have achieved to date as well (The Village Niagara, "Niagara-on-the-Lake", 2016).

Another key feature of new urbanism is the provision of a range of parks, "from tot-lots and village greens to ball fields and community gardens", which should be distributed within neighbourhoods; conservation areas and open lands should also be used to define and connect 
different neighbourhoods and districts (Congress for the New Urbanism, "The Charter", n.d.). When assessing the master-plan of The Village, the attempts made to incorporate the environmental and natural landscapes of the town while providing open public green space is evident throughout. Adjacent to the Village Centre is a public square and farmers' market of open land where in the summer months, the Market has already produced a gathering place for both locals and visitors to find a genuine community experience as well as good local food originating from the Niagara Region. In addition, there are a handful of parkettes and public parks spaced throughout the community that are available for use and are hoped to be used in the future for community fitness programs and natural playground style features. Ensuring that a healthy provision of open spaces and natural elements were available for both locals and visitors was an important aspect of the movement that Hawley wanted to ensure was present in the development.

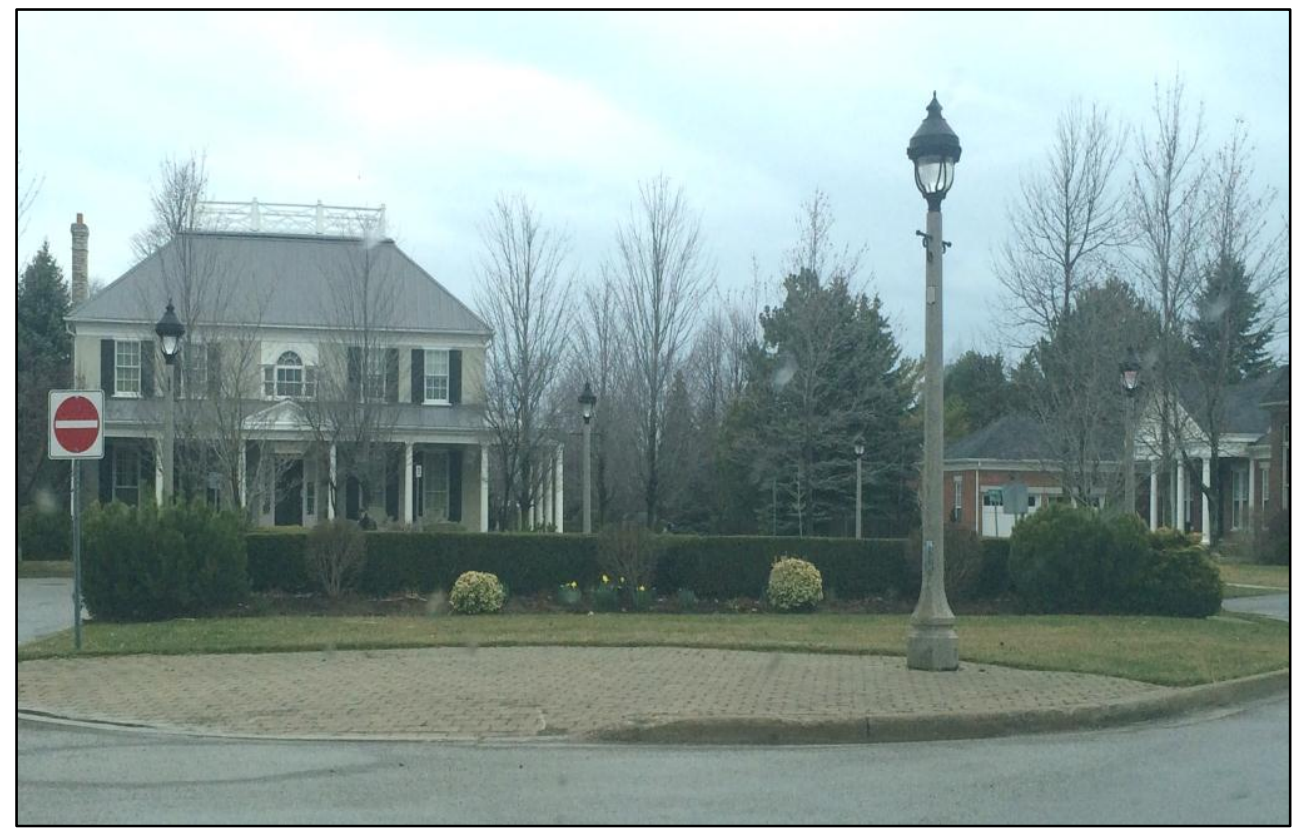

Figure 8 Parkettes and public gardens are evident throughout The Village 


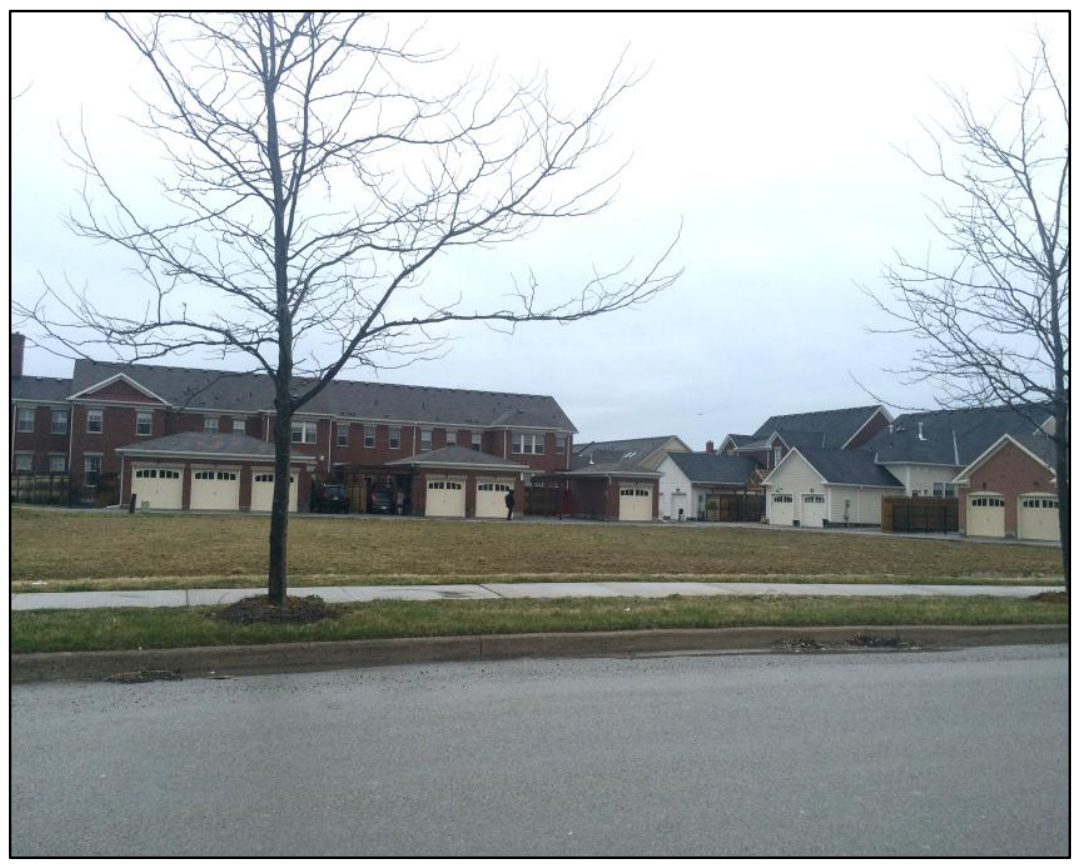

Another element that demonstrates the connection to the natural environment is evident along the development of housing that is adjacent to the Ravine and Two Mile Creek which borders one edge of the site. In a typical CSD, these houses would be front facing towards the street, and their rear private spaces would look out onto the Ravine. What is unique to The Village is that instead, a pedestrian path is to be built that follows the lay of the Ravine, and the homes are to be front-facing towards the Ravine, with the intention of making the Ravine and its natural heritage a feature of the public realm rather than a private space that would typically only be enjoyed by those residents backing onto it. Taking a cue from Kentlands in Washington, DC which also employed this method, it indicates another attempt at ensuring the public realm is continuously one of the most important aspects of The Village and provides a welcoming experience in all senses to residents and visitors alike.

The provision of access to transit is a key feature of new urbanism that advocates and critics love to discuss. The Charter stipulates that the physical organization of the region should be 
supported by a framework of transportation alternatives. Transit, pedestrian, and bicycle systems should maximize access and mobility throughout the region while reducing dependence upon the automobile. Transit can be a successful asset when located properly, managed well, and supported by favourable land-use patterns (Ellis, 2002). However, often efforts to incorporate a balanced transportation system based on new urban principles can be blocked by a lack of political will and existing policies, building practices and built forms (Ellis, 2002). This is very representative of the case in Niagara-on-the-Lake.

A central feature absent from The Village is accessibility to a transit system to encourage less reliance on the automobile. While there is one transit stop in the Village Center that residents can use, there are strict restrictions on who can use the transit, and limited opportunities for where this transit system will take someone. However, this is another feature of the development that is beyond the control of the developer, and is not to say that in the future were a transit system to become an available feature of the Town itself that every effort would be made to integrate it into The Village streetscape. Given Niagara-on-the-Lake's geographic location within the Region, residents are very car-oriented. At the same time, it is difficult to find the need for a transit system in a rural community of 16,000 people.

What The Village does offer is new urbanist street patterns and land-use mixtures that offer many advantages for pedestrians and cyclists. New urban street patterns in The Village provide for the reduction of speeds in a number of ways, with planned curves in the road and short streets, and the inclusion of boulevards and triangular right of ways to encourage slower and careful driving habits to the benefit of cyclists and pedestrians. The Village also incorporates narrower rights of ways, and when looking at the built-form itself, the houses have purposely 
been built close to the street which contributes considerably to the slowing down of vehicles as well.

Additional features that can be found in The Village are intrinsic to the principles of New Urbanism which further support the argument that despite certain elements being absence, as a whole and based on the extent to which the features which have been selected have been incorporated, it in no way detracts from the overall new urbanist classification that The Village has established. One such feature is the inclusion of a number of terminating vistas carefully planned for the end of every street in The Village. Terminating vistas are a building that stands in the middle of a road, so that when one looks up the street it ends with an aesthetically pleasing view within the street. This contributes to the principle that streets and squares should be safe, comfortable, and interesting to the pedestrian.

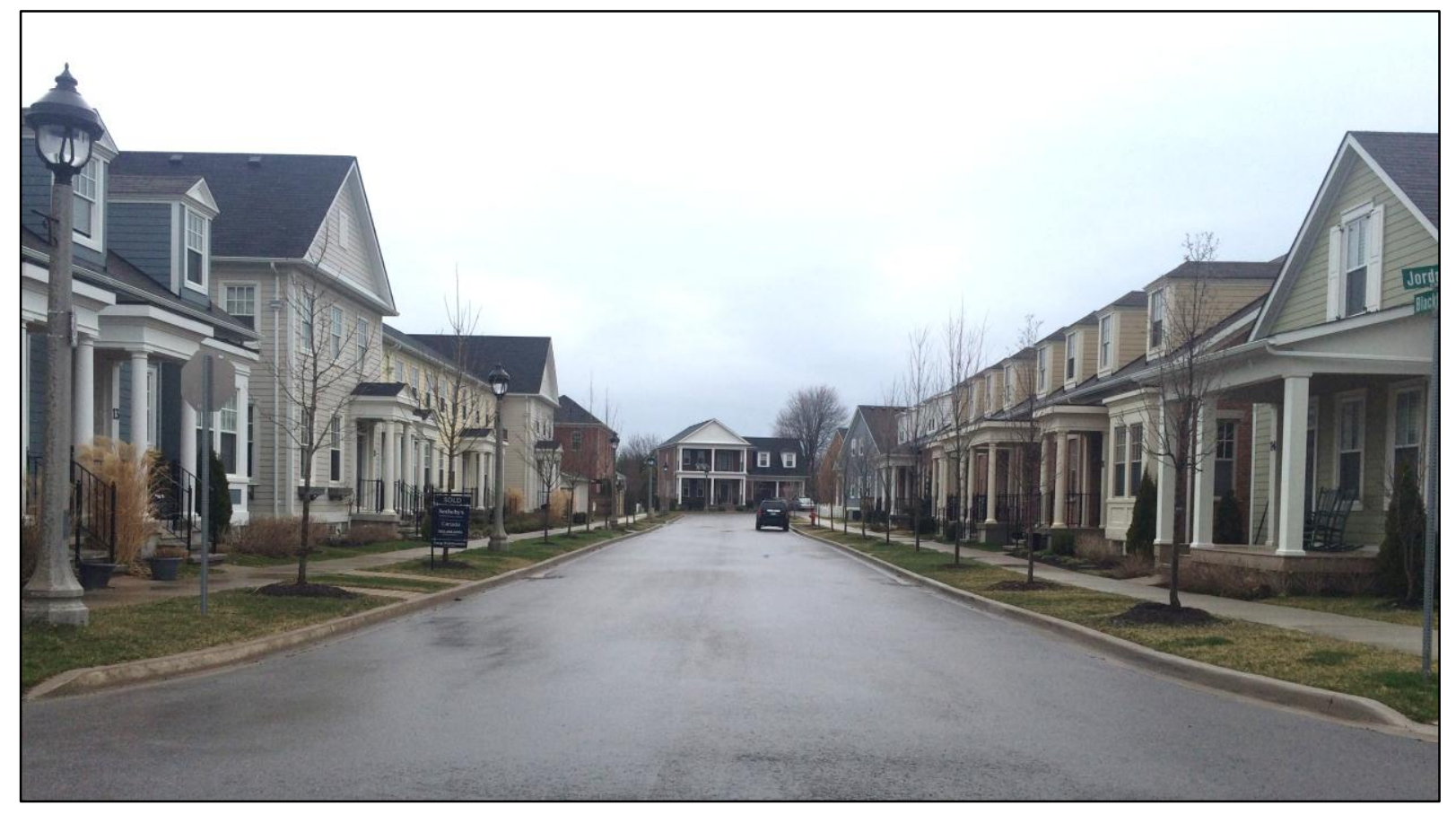

Figure 20 The presence of a terminating vista, which are planned for almost every road throughout The Village, as well as evidence of narrow streets and sidewalk provision on both sides 
As well, The Village contributes to the principle that neighbourhoods should be compact, pedestrian friendly, and mixed-use. The Village provides a mixed commercial residential space in the community of Niagara-on-the-Lake. The Village Centre is considered to be the heart of The Village community, located visibly at the entrance to the development towards the west. Upon its completion it will feature shops, services, galleries, professional offices, cafes and restaurants that are unique to Niagara. The provision of commercial and retail services in new urbanist developments is meant to be supportive of the local retail needs of the residents living in that development. It is hard to say with certainty whether The Village is reflective of this need at this point in time.

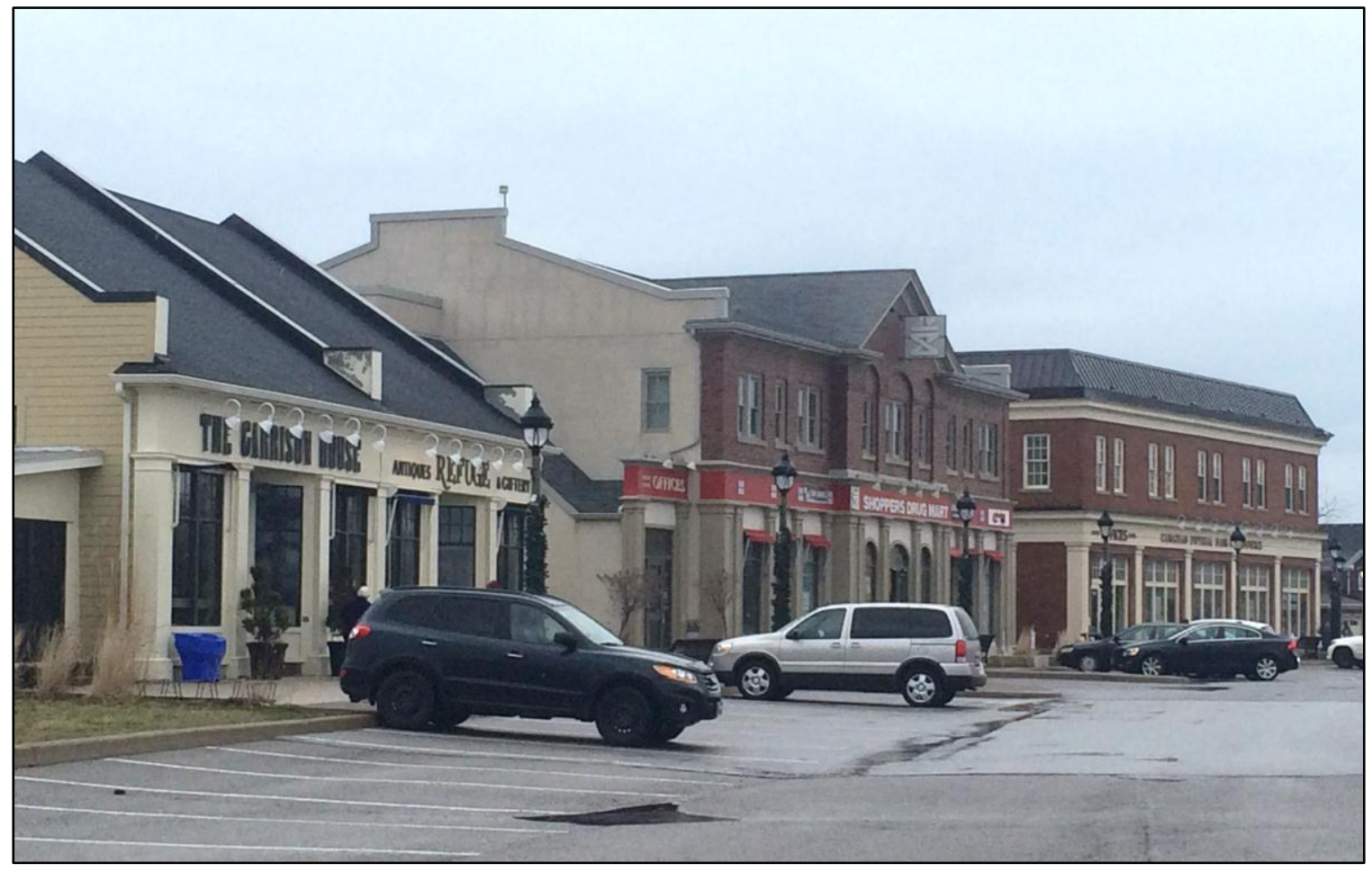

Figure 31 Commercial services provided in The Village Centre 
The provided services that have been built to date include a restaurant, antique shop, a retail drug store marketplace, and a bank, with office spaces for professional services on the top floors of these buildings, including dentistry, legal practices, accounting and real estate. The commercial area has a large amount of development still to be accomplished, and provision of the specific details of all future retail uses have yet to be provided to the public so it would not be reasonable to make a conclusive judgement on this characteristic of new urbanism at the time being.

Many activities of daily life can all be accomplished within walking distance from one another in The Village, and allow for independence for those who cannot drive, while encouraging walking and social interaction. The commercial area itself also benefits from being located on Hwy 55, serving the community in its entirety as well as traveling tourists. This is important because if it were to be self-contained to the neighbourhood alone, it would be much more difficult for businesses to thrive. Finally, the Charter suggests that the development of towns and cities should defer to historical patterns, precedents and boundaries, and it can be confidently said that The Village accomplishes this to the utmost respect.

Development of The Village was focused particularly on optimizing the quality of life of its residents, while honouring the culture and heritage that is special and unique to the historic Town of Niagara-on-the-Lake. The Village has been meticulously researched, planned and implemented; gradually growing from a basic skeleton master-plan that provides the basis of any well designed new urbanist community. Hawley states that as long as this original and individual skeleton of a master-plan is in place, there is no way in which a planned new urbanist community cannot be considered new urbanist.

From this analysis the resonating thought that has grown from this case study is that, in assessment of new urbanist communities from this point forward, perhaps rather than focusing 
on which principles of new urbanism may or may not be absent from a development, the true characterization of whether a community really embodies new urbanism should be examined based on how purely and intricately that the elements that have been precisely selected are carried out to their fullest new urban extents. "From the integrity of the Master Plan to the convenience of our vibrant Village Centre, the careful design of our streets to the strategic placement of porches and parks" (The Village Niagara, 2016), The Village provides exceptional evidence of attention to even the littlest and most elaborate of details that it would be difficult for any such critic to suggest that solely on the basis of a few missing elements, this community is not new urbanist. 


\section{Conclusion}

Grant (2006) has suggested that Canadian new urbanism has tended to follow in the American model of new urbanism, using traditional neighbourhood development principles and inclined to use the language of urban villages. However, Canadian practices of new urbanism have ventured towards using an adjustment of planning policies in order to achieve the same principles that their American counterparts so heavily relied on codes and contracts to master. In The Village, we have been provided with evidence of both such practices, and perhaps have found a means of inspiring future new urban developments to abound in Ontario using these methods.

Critics of Canadian new urban developments to date have suggested that a number of critical tenets of the new urbanist movement have been lacking in a majority of these developments (Grant, 2006). These aspects include a lack of affordability, catering to an upscale market, creating relatively little difference in automobile behaviours, and contributing to a loss of landscape function and agriculture lands (Grant, 2006). However, The Village has presented quite an interesting case study in the literature of new urbanism developments. While its shortcomings have been identified and in some ways do contribute convincingly to the arguments against new urbanism in Canada thus far, it is debateable that in assessment of its positive aspects and attributes, the trueness to new urban form of these elements and the attention to particularity of the new urbanism principles which were chosen far outweighs any areas in which it may experience inadequacies.

Research suggests that many Canadian planners are hesitant to identify their practices as new urbanism, but rather being discussed in Canadian practice as simply 'good planning principles' (Grant, 2006). Municipalities are more frequently adopting design guidelines and modified land use regulations to encourage and integrate new urban principles into their planning practices, and 
it is rare to find a planner that does not believe in the benefits of mixed-use, compact development, or pedestrian-friendly environments. Unfortunately, supply for new urban development continues to be constrained by land use controls that do not lend well to implementing important elements of new urbanism, in combination with 'not-in-my-backyard' (NIMBY) opposition, developer unfamiliarity with new urban designs, and the conservatism of municipal governments and institutions. This being said, those planners and developers that have acknowledged a true desire to learn and understand new urbanism, to incorporate it to the truest extent into Canadian communities have created the opportunity for these obstacles to be reduced, and allow the new urbanism's true market potential to grow over time.

New urbanism has motivated developers to focus on the public realm rather than the private space of one's property, and it is more than apparent that The Village has attempted to fulfil this principle in the utmost respect. As well, the integration of neighbourhood parks, people-friendly streetscapes, spaces for human interaction and enhancement of a sense of community as well as paying respect to the historical and cultural heritage of the place in which development is occurring are features of The Village that adhere especially to the concept of new urbanism and contribute significantly to its complete embodiment of the movement in practice.

Critics of the movement may suggest that without the integration of all the principles of the concept into a development it detracts from the true essence of new urbanism in practice. However, The Village presents a case study to add to the literature that demonstrates that rather than focusing on the principles themselves, it may be time to expand the definition of how a new urban development is assessed. This includes using Trudeau's (2013) typology of Dense Urbanism, Mainstream Urbanism, and Hybrid Urbanism, but also using a more in-depth and 
focused analysis of the carrying out of the principles themselves to assess the varying degrees with which these can contribute to the purity of new urbanism in practice. 


\section{Appendix A:}

\section{Charter Criterion Compared to its Satisfaction of Practical Application in The Village}

\begin{tabular}{|c|c|c|}
\hline & Charter Criteria & Satisfaction in The Village \\
\hline 1) & $\begin{array}{l}\text { Metropolitan regions are finite places with geographic } \\
\text { boundaries derived from topography, watersheds, coastlines, } \\
\text { farmlands, regional parks, and river basins. The metropolis is } \\
\text { made of multiple centres that are cities, towns, and villages, each } \\
\text { with its own identifiable centre and edges. }\end{array}$ & $\begin{array}{l}\text { The Village is made of a single central } \\
\text { area but is clearly defined by its urban } \\
\text { boundaries and edges. }\end{array}$ \\
\hline 2) & $\begin{array}{l}\text { The metropolitan region is a fundamental economic unit of the } \\
\text { contemporary world. Governmental cooperation, public policy, } \\
\text { physical planning and economic strategies must reflect this new } \\
\text { reality. }\end{array}$ & $\begin{array}{l}\text { Governmental cooperation, public } \\
\text { policy, physical planning and economic } \\
\text { strategies are reflected. }\end{array}$ \\
\hline 3) & $\begin{array}{l}\text { The metropolis has a necessary and fragile relationship to its } \\
\text { agrarian hinterland and natural landscapes. The relationship is } \\
\text { environmental, economic and cultural. Farmland and nature are } \\
\text { as important to the metropolis as the garden is to the house. }\end{array}$ & $\begin{array}{l}\text { As a result of its rural, greenfield } \\
\text { location and incorporation of natural } \\
\text { areas and conservation features, this } \\
\text { relationship is evident throughout. }\end{array}$ \\
\hline 4) & $\begin{array}{l}\text { Development patterns should not blur or eradicate the edges of } \\
\text { the metropolis. Infill development within existing urban areas } \\
\text { conserves environmental resources, economic investment, and } \\
\text { social fabric, while reclaiming marginal and abandoned areas. } \\
\text { Metropolitan regions should develop strategies to encourage such } \\
\text { infill development over peripheral expansion. }\end{array}$ & $\begin{array}{l}\text { The Village satisfies these criteria in that } \\
\text { it is a greenfield development that has } \\
\text { been interwoven into surrounding } \\
\text { neighbourhood character while } \\
\text { conserving environmental resources and } \\
\text { social fabric. }\end{array}$ \\
\hline 5) & $\begin{array}{l}\text { Where appropriate, new development contiguous to urban } \\
\text { boundaries should be organized as neighbourhoods and districts, } \\
\text { and be integrated with the existing urban pattern. Non-contiguous } \\
\text { development should be organized as towns and villages with } \\
\text { their own urban edges, and planned for a jobs/housing balance, } \\
\text { not as bedroom suburbs. }\end{array}$ & $\begin{array}{l}\text { The Village has been integrated into the } \\
\text { adjacent built-up urban areas and } \\
\text { subdivision, and is distinguished by its } \\
\text { own edges. It incorporates a commercial } \\
\text { retail area, and has plans for future } \\
\text { live/work housing. }\end{array}$ \\
\hline 6) & $\begin{array}{l}\text { The development and redevelopment of towns and cities should } \\
\text { respect historical patterns, precedents, and boundaries. }\end{array}$ & $\begin{array}{l}\text { Architectural codes and development } \\
\text { have meticulously respected the heritage } \\
\text { and character found in the Town of } \\
\text { Niagara-on-the-Lake. }\end{array}$ \\
\hline
\end{tabular}


7) Cities and towns should bring into proximity a broad spectrum of public and private uses to support a regional economy that benefits people of all incomes. Affordable housing should be distributed throughout the region to match job opportunities and to avoid concentrations of poverty.
This criterion was not met, albeit due to circumstances beyond the developer's control as affordable housing is not required in the Official Plan of Niagaraon-the-Lake and surrounding property values do not allow for this to be a reality.

8) The physical organization of the region should be supported by a framework of transportation alternatives. Transit, pedestrian, and bicycle systems should maximize access and mobility throughout the region while reducing dependence upon the automobile.

Although a public transit system is limited in the municipality, it impacts the ability of this characteristic to be realized, sufficient pedestrian and bicycle systems have been provided.
9) Revenues and resources can be shared more cooperatively among the municipalities and centres within regions to avoid destructive competition for tax base and to promote rational coordination of transportation, recreation, public services, housing, and community institutions.
There is evidence of this factor being incorporated into the production of the development, but more quantifiable data has yet to be realized.
10) The neighbourhood, the district, and the corridor are the essential elements of development and redevelopment in the metropolis. They form identifiable areas that encourage citizens to take responsibility for their maintenance and evolution.
Being a part of the Old Town of Niagaraon-the-Lake, The Village residents have committed to demonstrate respect and care for the many areas that make up the neighbourhood.

11) Neighbourhoods should be compact, pedestrian friendly, and mixed-use. Districts generally emphasize a special single use, and should follow the principles of neighbourhood design when possible. Corridors are regional connectors of neighbourhoods and districts; they range from boulevards and rail lines to rivers and parkways.

12) Many activities of daily living should occur within walking distance, allowing independence to those who do not drive, especially the elderly and the young. Interconnected networks of streets should be designed to encourage walking, reduce the number and length of automobile trips, and conserve energy.

The Village has been carefully planned as a compact, pedestrian friendly and mixed-use development.
Curved street design, the use of boulevards, narrow right of ways and other traffic calming measures as well as sidewalks clearly indicate the desire to encourage walking. The Village Centre is within close walking distance from the all parts of the area. 
13) Within neighbourhoods, a broad range of housing types and price levels can bring people of diverse ages, races, and incomes into daily interaction, strengthening the personal and civic bonds essential to an authentic community.
Every effort has been made to provide a diversity of housing types. However, the market and surrounding land values restrict the availability of a range of price levels which significantly limits different income levels from residing in The Village.

14) Transit corridors, when properly planned and coordinated, can help organize metropolitan structure and revitalize urban centres. In contrast, highway corridors should not displace investment from existing centres.

Planning has incorporated an access point from the nearest highway corridor, and corridors contribute to the overall coordination of the development.

15) Appropriate building densities and land uses should be within walking distance of transit stops, permitting public transit to become a viable alternative to the automobile.

The Village provides a transit stop twice daily in The Village Centre for the Town's limited transit system.

16) Concentrations of civic, institutional, and commercial activity should be embedded in neighbourhoods and districts, not isolated in remote, single-use complexes. Schools should be sized and located to enable children to walk or bicycle to them.

While The Village provides access to a number of civic, institutional and commercial activities in built-up areas within close proximity, circumstances prevent easy access to schools, or for schools to be built within The Village boundaries.
17) The economic health and harmonious evolution of neighbourhoods, districts, and corridors can be improved through graphic urban design codes that serve as predictable guides for change.
The architectural regulatory codes of The Village have been impeccably planned with significant attention given to planning and building in the future.

18) A range of parks, from tot-lots and village greens to ball fields and community gardens, should be distributed within neighbourhoods. Conservation areas and open lands should be used to define and connect different neighbourhoods and districts.

The Village has greatly succeeding in meeting these criteria; a range of parks of varying sizes, green open areas and gardens, and natural conservation areas have been incorporated and planned into the neighbourhood.

19) A primary task of all urban architecture and landscape design is the physical definition of streets and public spaces as places of shared use.

This feature has been realized as evidenced by the placement of sidewalks, prevalence of porches, proximity of houses to the street, and use of rear laneways to encourage a focus on the public realm. 
20) Individual architectural projects should be seamlessly linked to The Village achieves this aspect. their surroundings. This issue transcends style.

21) The revitalization of urban places depends on safety and security. The design of streets and buildings should reinforce safe environments, but not at the expense of accessibility and openness.

The master-plan demonstrates that the concept of accessibility and openness has been considered throughout, and observance of resident usage has demonstrated the feeling of a safe environment.

22) In the contemporary metropolis, development must adequately accommodate automobiles. It should do so in ways that respect the pedestrian and the form of public space.

Rear laneways and carefully placed parking lots have provided accommodation for vehicles while preserving the connection to the public realm.

23) Streets and squares should be safe, comfortable, and interesting to the pedestrian. Properly configured, they encourage walking and enable neighbours to know each other and protect their communities.

Architectural features of the properties and design patterns of the streets indicate a desire to encourage residents to use pedestrian walkways and interact with one another in the public space in front of homes.

24) Architecture and landscape design should grow from local climate, topography, history, and building practice.

The developer of The Village has indicated a willingness to work with local engineers to design street patterns so as to allow for snow removal, storm water management is contained underground of open natural areas, and the Codes have incorporated climate conditions into their design features.

25) Civic buildings and public gathering places require important sites to reinforce community identity and the culture of democracy. They deserve distinctive form, because their role is different from that of other buildings and places that constitute the fabric of the city.

The Village does not feature any distinct civic buildings.

However a public gathering place allows for integration and community engagement to occur amongst residents and visitors to the neighbourhood, and this area is a distinct space in The Village Centre. 
26) All buildings should provide their inhabitants with a clear sense of location, weather and time. Natural methods of heating and cooling can be more resource-efficient than mechanical systems.

27) Preservation and renewal of historic buildings, districts, and landscapes affirm the continuity and evolution of urban society.
The architectural Codes again demonstrate that through window design, window placement, and direction of buildings these natural conditions have been taken into consideration.

The Village has succeeded in seamlessly fitting itself into the surrounding heritage area, matching character and architectural styles so as not to distract from . 


\section{$\underline{11 . \text { References }}$}

Banerjea, N. (2015). New urbanism. Salem Press Encyclopedia.

Brookfield Residential. (2016). Niagara-on-the-Lake The Village. Retrieved from http://brookfieldhomes.ca/community/the-village/new-homes

Calthorpe, P. (2013). Afterword: CNU Expanded. In Talen, E. (Ed). (2013). Charter of the New Urbanism: Congress for the New Urbanism $2^{\text {nd }}$ Edition. New York, NY: McGraw-Hill Education.

Congress for the New Urbanism. (n.d.). The Charter of the New Urbanism. Retrieved from https://www.cnu.org/who-we-are/charter-new-urbanism

Congress for the New Urbanism. (n.d.). The Movement. Retrieved from https://www.cnu.org/who-we-are/movement.

Congress for the New Urbanism. (n.d.). The Organization. Retrieved from https://www.cnu.org/who-we-are/organization

Duany, A. \& Talen, E. (2002). Transect Planning. Journal of the American Planning Association, 68:3, 245-266.

Duany, Plater-Zyberk \& Company. (2007). The Village of Niagara-on-the-Lake Codes Architectural Regulations [pdf document].

Ellis, C. (2002). The new urbanism: Critiques and rebuttals. Journal of Urban Design, 7(3), 261291.

Fulton, W. (1996). The New Urbanism Challenges Conventional Planning. Land Lines, 8(5). Retrieved from http://www.lincolninst.edu/pubs/508_The-New-Urbanism-ChallengesConventional-Planning

Garde, A. (2004). New Urbanism as Sustainable Growth?: A Supply Side Story and Its Implications for Public Policy. Journal of Planning Education and Research 24, 154-170.

Government of Ontario. Ministry of Public Infrastructure Renewal. (2006). Places to Grow: Growth Plan for the Greater Golden Horseshoe. Retrieved from https://notl.civicweb.net/document/3882/FINAL-PLAN-ENGALL.pdf?handle=A3B9948EB94145E9BA63485C366881B9

Grant, J. (2006). Planning the Good Community: New Urbanism in Theory and Practice (1st ed.) Routledge. 
Grant, J. L., \& Bohdanow, S. (2008). New Urbanism Developments in Canada: A survey. Journal of Urbanism: International Research on Placemaking and Urban Sustainability, 1(2), 109-127.

Grant, J. L. (2009). Theory and practice in planning the suburbs: Challenges to implementing new urbanism, smart growth, and sustainability principles. Planning Theory \& Practice, 10(1), 11-33.

Jacobs, K. (2011, January 27). Driving: Florida's New Urbanist Experiments. Retrieved from http://www.travelandleisure.com/articles/paradise-usa

Poticha, S. (2013). Forward. In Talen, E. (Ed). (2013). Charter of the New Urbanism: Congress for the New Urbanism $2^{\text {nd }}$ Edition. New York, NY: McGraw-Hill Education.

Talen, E. (Ed). (2013). Charter of the New Urbanism: Congress for the New Urbanism $2^{\text {nd }}$ Edition. New York, NY: McGraw-Hill Education.

Town of Niagara-on-the-Lake. (2012). Niagara-on-the-Lake Current Situation Report and SWOT Analysis [pdf document]. Retrieved from https://notl.civicweb.net/document/3302/CSR\%20Report\%20and\%20SWOT\%20Analysi s\%20-\%20August\%202012.pdf?handle =473F2ED03C7C4EBAB3397129CC63ED86

Trudeau, D. (2013). A typology of New Urbanism neighborhoods. Journal Of Urbanism, 6(2), 113-138.

Trudeau, D., \& Malloy, P. (2011). Suburbs in Disguise? Examining the Geographies of the New Urbanism. Urban Geography, 32(3), 424-447.

The Village Niagara. (2016). Welcome to the Village. Retrieved from http://thevillageniagara.com/

The Village Niagara. (n.d.) A Historic Beginning. Retrieved from http://thevillageniagara.com/about/a-historic-beginning/

The Village Niagara. (n.d.). Niagara-on-the-Lake. Retrieved from http://thevillageniagara.com/about/niagara-on-the-lake/

The Village Niagara. (n.d.) Understanding New Urbanism. Retrieved from http://thevillageniagara.com/about/new-urbanism/

Walker, A. (2014, April 18). Why is New Urbanism So Gosh Darn Creepy? Retrieved from http://gizmodo.com/why-is-new-urbanism-so-gosh-darn-creepy-1564337026 